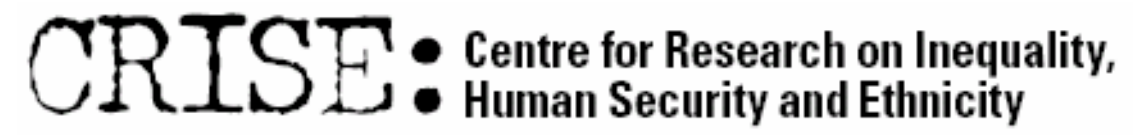

Queen Elizabeth House, University of Oxford

\title{
Horizontal inequalities: Explaining persistence and change
}

\section{Frances Stewart and Arnim Langer CRISE WORKING PAPER No. 39 August, 2007}

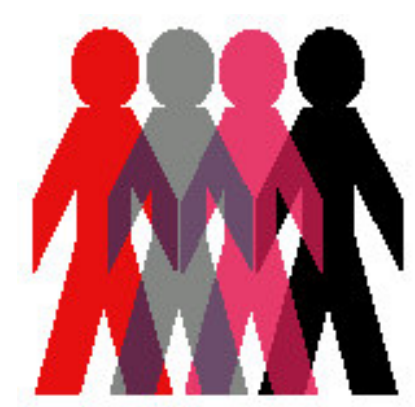




\title{
Horizontal inequalities: Explaining persistence and change
}

\begin{abstract}
In many cases Horizontal Inequalities or inequalities among groups (HIs) persist over long periods. Where they persist they are particularly deleterious as they trap people, generation after generation, in a situation of poverty. These conditions may also give rise to greater social instability. Consequently, this paper is devoted to understanding the determinants of socio-economic Hls over time, why they are so persistent in some cases but prove temporary in others. It does so by presenting a general framework in which complementarities between the productivity and accumulation of different types of capital tend to lead to self-perpetuating cycles of success and failure, particularly given the asymmetric social capital between different identity groups. Case studies of HIs over time in Peru, Ghana and the United States illustrate the persistence of Hls and the reasons for this; the examples of Northern Ireland and Malaysia show that Hls can narrow sharply, given strong government interventions; some Asian immigrant groups in the US (Filipino and Japanese) have caught up without government intervention, primarily because the immigrants were selected as having high levels of human capital and they brought with them a culture of achievement. The conclusion is that persistence of HIs is not inevitable, but interventions are generally needed in relation to both human capital accumulation and economic disadvantage if groups are to catch up
\end{abstract}

\section{The authors}

Frances Stewart is Professor of Development Economics at the University of Oxford and Director of the Centre for Research on Inequality, Human Security and Ethnicity (CRISE), Department of International Development, University of Oxford.

Email: frances.stewart@qeh.ox.ac.uk

Arnim Langer is CRISE Research Officer in Economics and Politics, West Africa.

Email: arnim.langer@qeh.ox.ac.uk 


\section{$\underline{\text { Table of Contents }}$}

1. Introduction 3

2. A framework for considering the evolution of HIs ................................................ 5

3. Evidence for the persistence and change of HIs............................................ 13

3.1 Education, labour markets and persistent inequality in Peru........................ 13

3.2 North-south inequalities in Ghana........................................................ 14

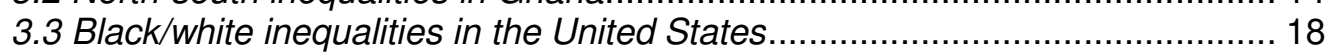

3.4 Protestant/Catholic inequalities in Northern Ireland ..................................... 20

3.5 Malay/Chinese inequalities in Malaysia .................................................... 23

3.6 Japanese, Chinese and Filipino immigrants in the United States.................. 25

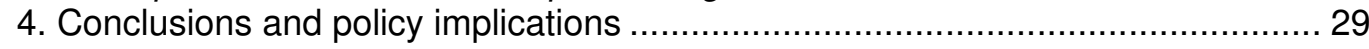

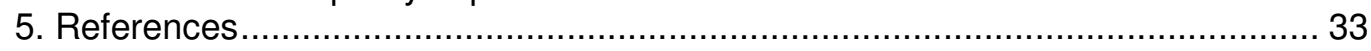

\section{List of Figures}

Figure 1: Variations in returns to social capital according to other assets ................. 8 Figure 2: Variations in returns to financial capital according to group discrimination.. 9 Figure 3: Interethnic differences in returns to education in Peru ............................. 14 Figure 4: The evolution of horizontal inequalities in Northern Ireland...................... 22 Figure 5: The evolution of different horizontal inequality indicators in Malaysia, ...... 23 Figure 6: The evolution of income inequalities in Malaysia, 1970-2002 ................... 25

\section{List of Tables}

Table 1: Educational inequality in Peru, 2003............................................... 13

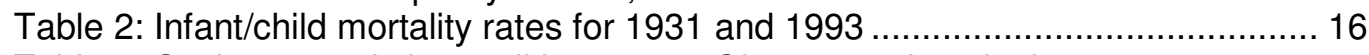

Table 3: Socioeconomic inequalities across Ghana's regions in the 1990s ............. 17

Table 4: Wealth by income and race .............................................................. 18

Table 5: College attendance and completion by race, person 25 or older, 1960-1995

Table 6: The evolution of educational differences between whites, blacks and three Asian immigrant groups in the US, 1940-1990 ............................................... 27

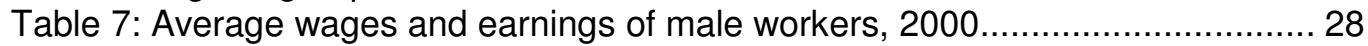




\section{Horizontal inequalities: Explaining persistence and change By Frances Stewart and Arnim Langer ${ }^{1}$}

\section{Introduction}

There is evidence that in many cases horizontal inequalities, or inequality among groups, persist over long periods. For example, black/white differentials in the US, or indigenous/Ladino differentials in Latin America, have been in existence for centuries. Other examples include the Northern peoples in Ghana and blacks in South Africa. Yet, in contrast, some immigrant groups who were initially poor relative to the national average soon achieved above-average incomes. Where Hls persist they are particularly deleterious as they trap people, generation after generation, in a situation of poverty. These conditions may also give rise to greater social instability. Consequently, this chapter is devoted to understanding the determinants of socioeconomic Hls over time, why they are so persistent in some cases but prove temporary in others.

In considering this issue, we draw on previous work on the question, both theoretical and empirical. For example, Tilly has made important contributions on both fronts, mainly considering the US situation (Tilly, 1998). Recent work by Mogues and Carter (2005) has considered theoretical issues, this time with a greater focus on developing countries, while there have been a number of empirical studies with bearing on the issue (e.g. Adato et al, 2006; Borjas, 1992, 1995; Durlauf, 2002). These analyses have generally focussed on one or two elements accounting for Hls over time. We adopt a more comprehensive approach, aiming to incorporate the whole range of factors that are significant in explaining change in Hls over time, both economic and political. This comprehensive approach is important because of interactions among the various factors, which are relevant to persistence, and because it permits identification of a wider range of policies towards Hls.

In order to consider persistence of Hls over time, a prerequisite is that we can identify long-term cultural markers that differentiate the groups being considered. This involves not only the definitional issues involved in determining group boundaries, widely debated by anthropologists (e.g. about how to define the salient group boundaries necessary to identity HIs at a point in time, but also considering whether these same boundaries remain salient over time. As time proceeds, inter-marriage, migration and cultural and religious changes may mean that prior group boundaries become insignificant or dissolve altogether, while new salient groups may emerge. Thus in $11^{\text {th }}$-century Britain, the difference between Anglo-Saxons and Normans was important politically, but by the $21^{\text {st }}$ century, differences between these groups have all but disappeared and new salient group boundaries (e.g. between Moslems and Christians, or groups defined according to their migration status and country of origin, have emerged).

It is only possible to investigate the question of persistent Hls empirically where group boundaries also persist over time, i.e. where the groups themselves remain a salient category. There may be some circularity here, as the persistence of the salience of an identity may itself be partly dependent on the persistence of horizontal inequalities - since sharp Hls tend to stimulate group consciousness. We should note that because of this, empirical investigation will tend to overestimate the persistence of Hls, because cases where group boundaries cease to be of

\footnotetext{
${ }^{1}$ We are grateful to Graham Brown and Luca Mancini for helpful comments on a previous draft, and to participants at a Kiel conference and a Queen Elizabeth House seminar.
} 
significance or disappear completely will not be explored, and these are the cases where it is likely that Hls did not persist. But even if the examples we find of persistence exaggerate the issue for society as a whole, they are important in themselves, perhaps especially so because in other cases catch up occurs.

HIs are multidimensional, with the main dimensions being economic, social, political and cultural, and with numerous elements within each category. This multidimensionality is particularly important in understanding persistence because interactions among the dimensions and the elements within them are an important factor determining persistent deprivation and also persistent above average performance. For example, lack of access to education (a social inequality) may lead to low incomes (an economic one) and both may be responsible for and also caused by lack of political power. We shall elaborate on these causal interactions much more below.

Vertical inequality, or inequality among all individuals or households in a society, is also typically persistent (that is, a continuously high Gini coefficient), yet individuals or families may move in and out of poverty, in what has been defined as 'churning'. For example, one study in China found that 50 per cent of poverty in four rural provinces was transient (Jalan \& Ravallion, 2000). In Uganda, a study in the Central and Western regions showed that 24 per cent of households moved out of poverty in a 25-year period, 15 per cent moved into poverty, and 23 per cent were chronically poor - that is, poor over the whole period (Krishna et al, 2006). A study of developed countries found that, 'In most European countries, the combination of modest inequality and extensive mobility among the poor enabled virtually all families to avoid relative deprivation at least occasionally' (Duncan et al,1993: 215).

With persistent $\mathrm{HI}$, in contrast, individuals/families are 'trapped' to a greater degree because of the difficulties of moving across groups, so that a higher proportion of families in deprived groups remain deprived over time. In other words, persistent HIs imply lower levels of churning among the poorest group(s). This is confirmed by a range of studies. For instance, Duncan et al(1993), Devine et al. (1992) and Corcoran (1995) found much greater persistence of poverty among the black population in the US. A similar differentiation according to race was found by a study in rural Appalachia (Blee \& Billings, 1996). Moreover, evidence for Kenya and Madagascar shows that people in remote and poor agro-ecological sites show more persistent poverty than those in more favourable areas (Barrett et al, 2006).

Hence taking lifetime outcomes as the area of concern, the welfare cost of inequality is likely to be higher in relation to $\mathrm{HI}$ than $\mathrm{VI}$. Moreover, the possibilities and expectations that a person faces affect the extent to which inequality hurts them, so that group inequality can be more damaging for individual well-being than similar inequality among a homogeneous population because people in deprived groups may feel trapped in their situation. This applies even more when persistence occurs across generations. Hence the importance of the question being investigated in this paper.

The paper is organised as follows: the next section develops a theoretical framework for understanding the evolution of Hls over time. Section III draws on empirical examples of long-run HIs to illustrate what happens to HIs in a variety of cases, and which parts of our framework seem to account for the changes. Section IV concludes with some policy implications. 


\section{A framework for considering the evolution of Hls}

HIs are multidimensional, as noted above. In our framework, however, we focus initially on income as an outcome, and we point to political and social inequalities as a cause of the income inequalities. We start with income because it is a fundamental dimension of economic welfare and a source of many other inequalities; and because our understanding of the determinants of income and income inequality is considerably more advanced than it is with respect to other inequalities. However, in principle we can extend the approach to encompass other inequalities, and the empirical section contains information on a much wider range of inequalities than simply income.

To start with we consider the immediate causes of economic inequality among individuals at a point in time. Incomes of an individual are a function of assets which they have and the employment and productivity of that capital. Inequality between groups is then the consequence of inequality in asset ownership between groups and inequalities in the returns to these assets. Assets include land; financial assets; education; public infrastructure; and social capital. Each of these assets is somewhat problematic to define and quality and quantity interact. Thus land ownership can be defined in terms of acreage or value (taking into account quality, market opportunities, the nature of the property rights); financial capital measures the ability to buy productive assets, and the value of the asset depends on the nature of the financial instrument adopted; human capital may be defined as years of education and access to health services, or it may also include the quality and nature of that education and of health services and other influences on health outcomes. Social capital is the most difficult to define. It is intended to include all the influences on productive opportunities and productivity stemming from social interactions. ${ }^{2}$ The 'quantity' of social capital is normally measured by the size of the network an individual has access to, or the daily interactions a person has, but it could be defined also to include a measure of the quality of these interactions which clearly affect the returns to any amount of social capital when defined quantitatively.

For each asset then there is a major problem in differentiating the quantity a group owns of each asset and the returns on the asset. This arises particularly acutely in the case of social capital. We start, however, by assuming that we can make the distinction between quantity of an asset and the returns on that asset.

To simplify matters, we assume that an individual's income depends on just three types of asset, human capital, financial capital, and social capital. Land can be subsumed in 'private productive capital'; and public infrastructure clearly affects human capital (health and education), but it does go beyond it, and we need to reintroduce it later, especially in considering regional inequalities. Then the income of the ith individual in a population is equal to:

$$
y_{i}=f\left(h_{i}, p_{i}, s_{i}\right)
$$

Where $\mathrm{h}_{\mathrm{i}}, \mathrm{p}_{\mathrm{i}}, \mathrm{s}_{\mathrm{i}}$, is the human, financial capital and social capital of individual $i$, respectively. Adding up the capital and income of all members of a group and dividing by a group's size, we get the average incomes of each social group.

For group 1, average income of each group member is given by:

\footnotetext{
${ }^{2}$ According to the World Bank 'Social capital refers to the institutions, relationships, and norms that shape the quality and quantity of a society's interactions' (World Bank, website), cited in lisakka and Alanen 2006.
} 
$y_{1}=f_{1}\left(h_{1}, p_{1}, s_{1}\right)$

Where $h_{1}, p_{1}, s_{1}$ are the average human, financial and social capital available to each member of group 1. Assume the returns to each type of capital are $\mathrm{H}^{1}, \mathrm{P}^{1}, \mathrm{~S}^{1}$ then:

$y_{1}=f_{1}\left(h_{1}^{H 1}, p_{1}^{P 1}, S_{1}^{S 1}\right)$

and with two groups, 1 and 2, income Hls at time t, are given by:

$H I_{t}=\frac{y_{1}^{t}}{y_{2}^{t}}=\frac{f_{1}^{t}\left(h_{1 t}^{H 1 t}, p_{1 t}^{P 1 t}, s_{1 t}^{S 1 t}\right)}{f_{2}^{t}\left(h_{2 t}^{H 2 t}, p_{2 t}^{P 2 t}, s_{2 t}^{S 2 t}\right)}$

We should note that we are assuming that different groups may face different production functions (i.e. $H_{1}$ is not necessarily equal to $H_{2}, P_{1}$ to $P_{2}, S_{1}$ to $S_{2}$ ); moreover, we are not assuming that the returns are constant over time or in relation to each other. This complicates our presentation as it means we cannot present a CES production function, but it is important to the argument about the determinants of changing Hls over time.

In exploring group inequality at a point in time (i.e. equation 4), then, we need to consider inequalities in both access to and ownership of capital, and in the productivity of that capital, where the productivity of capital includes its use as well as its productivity in use (i.e. subsumes employment). There is evidence that not only does the capital available to different groups vary, but also the returns vary. For example, poorer groups (as individuals) consistently have quantitatively less human and financial capital (Barrón Ayllón, 2005). They also often appear to secure lower returns on the capital they have. For example, African-Americans have been shown to have lower returns for a given level of human capital, while lower returns, as well as less education quantitatively, have been shown to be a feature of minorities in Vietnam (van der Walle \& Gunewardena, 2001).

Moreover, social capital is not truly 'social' but is a property of groups, with networks biased to within group connections, and consequently less advantageous for poorer groups (see Bourdieu, 1986). This follows from the definition of social capital since it encompasses neighbourhood and group effects on behaviour, opportunities and productivity, including peer group and cultural impacts on behaviour and aspirations as well networks which may open up or facilitate opportunities. We can then differentiate the 'quantity' of social capital of a group, defined as the number of contacts the group as a whole has, from the quality of that social capital, defined as the impact of the network (quantity of contacts) on economic achievements. A common distinction is between 'bridging' and 'bonding' social capital, sometimes defined as between family or group and within family or group contacts. In general within group social networks exceed between group networks in quantity. For poor groups, bonding or within group contacts are likely to be of lower quality than bridging or between group contacts. For rich groups, the reverse may be true. A number of studies have demonstrated the importance of 'neighbourhood', 'ethnic group' and 'social connection' effects on opportunities and incomes empirically (Borjas, 1995; Cooper, Durlauf and Johnson, 1994; Datcher, 1982; and Corcoran, Gordon, Laren and Solon, 1989, all for the US; Adato et al., 2006, for South Africa; and Nurmela, 2006, for Finland). 
Thus less capital of each kind and lower returns on that capital can explain the existence of inequality among individuals/groups at a point of time. But this does not explain what happens over time. In the second period, $t+1, \mathrm{HI}$ will be:

$$
H I_{t+1}=\frac{f_{1}^{t+1}\left(h_{1(t+1)}^{H 1(t+1)}, p_{1(t+1)}^{P 1(t+1)}, S_{1(t+1)}^{S 1(t+1)}\right)}{f_{2}^{t+1}\left(h_{2(t+1)}^{H 2(t+1)}, p_{2(t+1)}^{P 2(t+1)}, S_{2(t+1)}^{S 2(t+1)}\right)}
$$

Changes in $\mathrm{HI}\left(\mathrm{HI}_{\mathrm{t}+1} / \mathrm{H}_{\mathrm{t}}\right)$ therefore depend on changing relative rates of accumulation of each type of capital, and changing returns to each type of capital. Thus it is possible that groups catch up over time, for example by accumulating more than the more privileged groups, or by catching up technologically and hence reducing differentials in returns. Moreover, for some of the non-income elements of Hls, notably health and education, there are upper limits to achievements (e.g. 100 per cent literacy is a maximum) so that some catching up is likely to arise from this 'boundedness's. But there are other reasons why catch up does not occur and inequality persists. We identify six factors in this respect.

Firstly, there are cumulative forces, such that deprivation/riches at one point in time make it harder/easier to accumulate assets in the future. If an individual has a higher income due to higher assets, then saving (including educating children) is easier, so we might assume that the rate of saving and accumulation is likely to be higher among richer individuals/groups. Banerjee and Newman (1993) have developed a theoretical model showing how capital market imperfections reduce job choices of the financial capital poor, and thus constrain earnings in subsequent periods. Moreover, in the case of human capital, there is a direct intergenerational impact on behaviour so that a major predictor of a child's education (and nutrition and health) is the education of her mother (Behrman, 1990; King and Hill 1993). In theory, 'perfect' capital markets should enable people to borrow to overcome the disadvantage of not having their own savings. But in practice, banks require collateral so that borrowing too is easier for the rich than for the poor. Loury (1981) shows how family income determines mobility in the absence of a perfect capital market for educational loans, leading to poverty traps.

Extensive empirical evidence shows that poorer individuals/groups accumulate less, both with respect to human and financial capital [refs2]. Although upper limits on education mean that once richer groups approach this level, their educational accumulation will be limited and a relatively faster rate of accumulation can be expected among poorer individuals/groups.

\footnotetext{
3 Empirical work on inter-country inequality shows much more convergence of human indicators than economic, probably for this reason.
} 
Secondly, there are interactions among returns to different types of capital according to the other types of capital a person/group has. Thus human capital permits greater earnings, which enable people to accumulate more; financial capital is more productive if people have human capital with which to use it; human capital may be more productively employed if people have financial capital; and both types of capital are likely to be better used with good networks (i.e. more social capital). In addition, social capital of a group improves as people within the group become better educated and richer so that people within the group have better educated and richer contacts.

This is illustrated in Figure 1, showing how returns to financial capital vary according to the level of other types of capital.

Figure 1: Variations in returns to social capital according to other assets

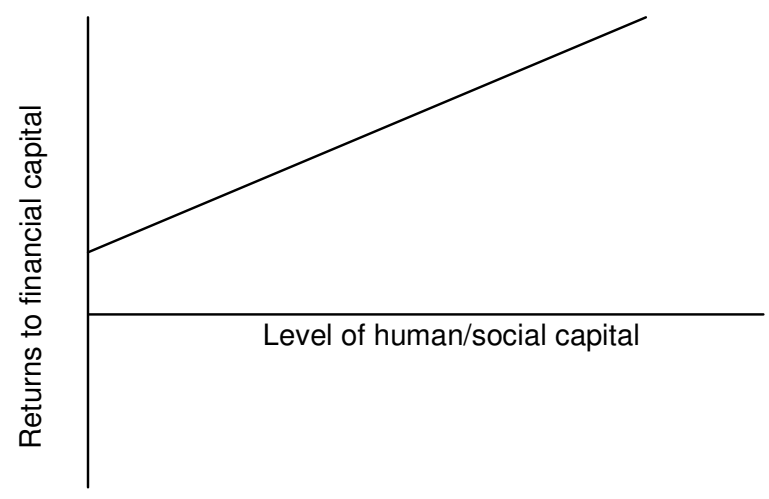

What this means is that the returns to one type of capital depend not only on the accumulation of that type of capital, but also on the accumulation of other types, so that, for example, $P$ (the returns to financial capital) depend on the level of human and social capital ( $h$ and $\mathrm{s}$ ). This is why we do not assume a CES production function and we posit different production functions for each group.

Thirdly, Hls might persist because of persistent asymmetries in social capital which then cause the unequal returns on other types of capital just noted. While asymmetry in social capital occurs among individuals - poor people tend to have more contacts with other poor people than with richer people - it applies even more strongly among groups. Indeed, some have defined groups as being collections of individuals whose transactions/contacts within group are significantly greater than their transactions outside the group (Blau, 1977). This effect has been modelled by Lundberg and Startz (1998) and Mogues and Carter (2005), while Durlauf (2002) shows how 'neighbourhood' effects can sustain poverty, via peer group effects, social learning and social complementarities. An empirical investigation into neighbourhoods in the US found that neighbourhood effects influence intergenerational mobility, while ethnic factors play an additional role even among people who grow up in the same neighbourhood (Borjas, 1995). Borjas also showed empirically that 'the skills and labor market outcomes of today's generation depend not only on the skills and labor market experiences of their parents but also on the average skills and labor market experiences of the ethnic group in the parent's generation' (Borjas 1992: 148). Neighbourhood effects (again in the US) have also been shown to influence the development of children and adolescents, including IQ and school leaving, with long term consequences for socio-economic outcomes 
(Brooks-Gunn, Duncan, Klebanov and Sealand 1993). There is empirical evidence for South Africa too that asymmetries of social capital have blocked pathways of social mobility even in the post-apartheid era (Adato et al, 2006). Based on panel data for 1993-1998, Adato et al, 2006: 244) concludes that 'social capital becomes more narrowly constructed and increasingly ineffective as a means of capital access for poor people in a country facing a legacy of horizontal inequality and social exclusion.'

Fourthly, Barrett, Carter and others have argued that there are discontinuities in returns to different types of capital, so that at low levels of capital, returns are low and people are trapped in a low-level equilibrium. This could be due to the type of interaction just discussed, i.e. returns on financial capital are low because of weak human capital and conversely, or because of other sources of discontinuity (for example, indivisibilities in capital). Poverty due to low level equilibria of this type has been defined as 'fractal poverty' (Barrett et al., 2006; Carter \& Barrett, 2006). To the extent that such discontinuities exist, incomes of low-income individuals/groups may grow slowly, while richer individuals/groups escape these discontinuities and show faster growth.

A fifth reason for the persistence of group inequality is that group members are often subject to overt (or implicit) discrimination or favouritism by non-group members in access to different types of capital and in employment, in virtue of their group (cultural) characteristics. This illustrated in Figure 2, which shows that Group 1 has higher returns to financial capital, for any level of human/social capital.

We should note that historic discrimination contributes to poor returns even where it seems there is no current discrimination. For example, unequal endowments today may be partly a reflection of past discrimination. Effects persist even if there is no current discrimination, that is even if, for example, there are equal employment opportunities for the same educational attainments, since past discrimination may have led to inequality in educational endowments (see e.g. Brown et al., 2005). Further, Loury (2002) argues that negative stereotypes about certain groups can become self-fulfilling which amounts de facto to (implicit) discrimination against the stereotyped groups. Thus, for instance, the negative stereotype that blacks do not work hard may result in a situation that employers with imperfect information are more likely to fire them. Consequently, blacks may decide that it is not worth working hard because they are likely to get fired anyway regardless of their individual work ethics. If blacks conform to a negative stereotype, their relatively poor treatment may appear to be justified and not be identified as due to discrimination, yet discrimination (via negative stereotypes) underlies the situation.

Figure 2: Variations in returns to financial capital according to group discrimination

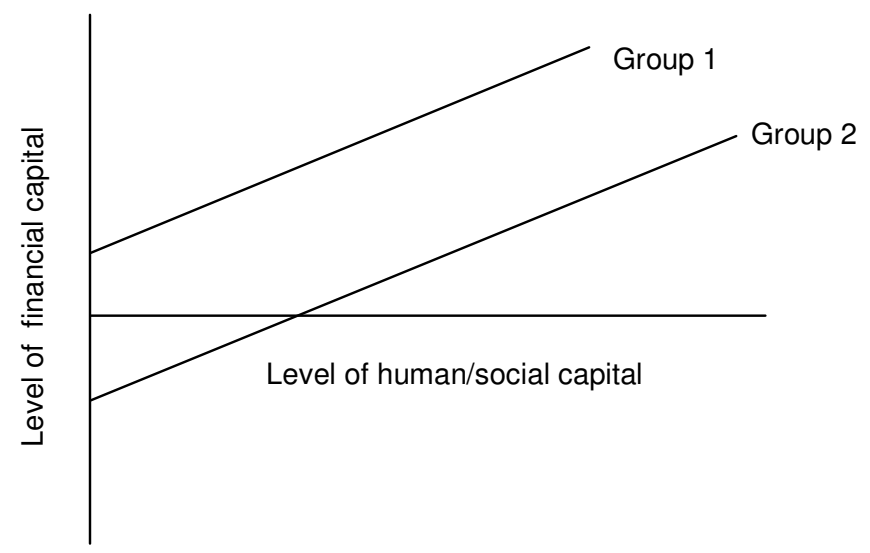


Finally, group inequalities in most cases include political inequalities in the same direction as the socioeconomic inequalities. This means those who are deprived in socioeconomic dimensions also lack political power. These political inequalities generally underpin the socioeconomic inequalities since they often lead to bias in the distribution of government resources, including access to social and economic services and government employment and contracts. Moreover, the political inequalities can prevent corrective action towards the relatively powerless group. In general, where political inequalities and socioeconomic inequalities are in the same direction, we would expect each to reinforce the other. But there are occasional cases where a majority (privileged) government takes action to help a deprived group, although this is generally not enough to eliminate the inequality (for example, affirmative action in the US or Brazil). One reason for such corrective action is that deprived groups may mobilise politically behind their common identity, putting effective pressure on governments for corrective action. This was the case in Northern Ireland, where government policy from the mid-1970s reduced centuries-old inequalities, as discussed further below. There are cases, in contrast, where political power and socio-economic deprivation are in opposite directions, as in the recent history of Malaysia or South Africa. In these cases, governments tend to take action to correct the socioeconomic Hls so that over time they can be expected to become less marked.

Returning to the key variables determining the direction in which economic Hls move over time:

- $h_{(t+1)} / h_{t}$ (or the relative accumulation of human capital): this is likely to diverge in the early stages of development because of differing rates of accumulation, but may converge as the richer groups attain high levels of education and further accumulation slows down. It may also converge because of government policy to spread education widely.

- $p_{(t+1)} / p_{t}$ (or the relative accumulation of financial capital): this may diverge because of differing rates of savings. Directed credit schemes may achieve some convergence.

- $s_{(t+1)} / s_{t}$ (or the relative accumulation of social capital): this might converge with the increased mobility that occurs with development as contacts increase, although richer groups may also upgrade their contacts over time (for example, internationally).

- $H_{(t+1)} / H_{t}$ (or the change in the relative returns to human capital): this could converge if the discontinuities and imbalances among types of capital have less effect when accumulation occurs among all groups. But we are in somewhat unknown territory here as to the precise interactions and discontinuities. Policies to reduce discrimination in employment - or to go further and introduced affirmative action - will affect this.

- $\quad P_{(t+1)} / P t$ (or the change in relative returns to financial capital): differences between rich and poor groups are likely to persist for reasons given above, but it is difficult to say whether these will increase or decrease over time. The normal neoclassical assumption of diminishing returns to capital accumulation may be offset by indivisibilities and technological change. In any case the tendency for diminishing returns is likely to apply at the level of the economy as a whole (i.e. for all groups) but not necessarily in relation to the returns to one group relative to another. Government policy is again potentially relevant here, since it can provide technological assistance targeted at deprived groups, or conversely further help the privileged groups. 
- $S_{(t+1)} / S_{t}$ (the change in the relative return to social capital): this is a matter of the quality or effectiveness of social capital - a question of among whom the interactions occur. As a group's education increases the quality of the interactions within group may improve. In addition, cross-group interactions may occur with increased development, and in response to government/civil society policies to increase them. Equally governments and civil society sometimes follow policies to reduce cross-group interactions.

One general feature which may reduce (or increase) group inequalities is a weakening (or tightening) of group boundaries. As group boundaries weaken - for example due to education, intermarriage and so on, -more people may switch groups, which would tend to reduce inequalities. Conversely, if governments or people themselves increase the tightness of group boundaries (for example, by categorising people, preventing mixing, mobilisation on identity lines), this element of group convergence will disappear. Even the categorisation of people into different groups for affirmative action purposes (for example, in the US and India), or for purposes of quota allocations (for example, in Nigeria and India), may contribute to an increase in the salience of group differences, which in turn inhibits the inequalityreducing mechanism of group-switching. It is argued, for example, that the Malaysian affirmative action policies have 'entrenched' group politics and difference, although without much supporting evidence (see e.g. Mandal, 2004). ${ }^{4}$

Migration - national and international - is another way that convergence might be achieved. In principle, migration can offer people/groups opportunities to improve their situation, thereby potentially reducing inequalities. But in practice, both formal and informal ${ }^{5}$ limits to migration often constrain this possibility. Internal migration is especially relevant in developing countries with severe climatic and ecological differences. However, although migration might improve the socioeconomic situation of the migrants relative to their region of origin, potentially reducing spatial HIs, it may establish a new set of unequal relations and mechanisms in the recipient areas, while leaving the sending areas without their most dynamic people. In Ghana and Côte d'Ivoire, for instance, a large number of people from the poorer and less wellendowed northern regions migrated to the southern regions in order to work on the cocoa and coffee plantations there. However, restrictions on land ownership and lack of resources meant that they were primarily employed as agricultural labourers on other people's land, thereby maintaining and to some extent further engraining the inequalities between 'southern' and 'northern' people. Another reason migration does not necessarily lead to a large reduction in Hls is related to the fact that the cities or regions to which people migrate are often unable to incorporate all the additional labour supply, resulting in high unemployment and poverty rates among the migrants. The development of vast slums and shanty-towns in a large number of developing countries, where migrants often live in dreadful conditions, is a clear indication that migration does not necessarily improve the socioeconomic situation of the migrants. The situation of immigrant populations in Europe also shows how new HIs can arise from migration.

To summarise, there are good reasons for expecting economic HIs to persist, although there are features which might lead to convergence. If a group starts from an unequal position, stemming from unequal access to different types of capital, key features sustaining such group inequality are:

\footnotetext{
4 'The racialisation of state initiatives like the New Economic Policy (NEP) have institutionalised race and made it part of an effective political system' Mandal, 2004: 58).

${ }^{5}$ Informal constraints include language and financial requirements for migration.
} 
1. Unequal rates of accumulation, due to inequalities in incomes and imperfect markets.

2. Dependence of the returns to one type of capital on the availability of other types.

3. Asymmetries in social capital.

4. Discontinuities in returns to capital.

5. Present and past discrimination by individuals and non-governmental institutions.

6. Political inequalities leading to discrimination by governments.

Of the six factors, groups as such are affected by 3,5 and 6 . The other reasons $(1,2$ and 4) apply to individuals as well as groups and thus explain persistent inequality in homogeneous societies. Previous work on persistent group inequalities has focussed on different elements among these six factors. For example, Tilly's important work categorised causes of persistence into discrimination, hoarding and emulation (see Tilly, 1998). Discrimination is explicitly included in reason 5 above. Hoarding consists in a privileged group introducing deliberate restrictions which favour it. This amounts to intervention in the market in such a way as to alter access to and returns to capital of various types. This could be thought of as an additional reason for unequal accumulation and for differential returns, or it might be encompassed in a particular type of asymmetric social capital. Emulation consists in the spread of this practice. Mogues and Carter (2005)have modelled asymmetries in social capital (reason 3) as responsible for persistent group inequality. Barrett and others have analysed discontinuities in returns as explaining persistence in individual poverty (reason 4) (see e.g. Barrett and Swallow, 2006), while Azariadis and Drazen (1990) have done the same to explain persistent inequality among countries, pointing to the low return to financial capital where there is relatively little human capital. In general, the political system has not been explicitly included in the analysis. Yet governments play an important role in furthering or reducing economic inequalities, so it is important that this too enters systematically into the analysis.

Taken together, these factors lead to the possibility of virtuous and vicious cycles with those groups starting in a privileged position being able to accumulate more, having higher returns to assets and thus sustaining their privilege, while those who start in an underprivileged position fall into a vicious cycle, or poverty trap (see also Galor \& Zeira, 1993). This is broadly the same as the accumulation and disaccumulation analysed by Brown et al. (2005) in explaining persistent racial inequality in the US. There is a parallel here with country performance in which poor economic performance handicaps human development and accumulation and poor human development handicaps economic growth (see Ranis, Stewart \& Ramirez, 2000).

What these six factors do not tell us is what causes the initial inequality which sets in motion the interactions leading to the persistence of HIs. An important and pervasive cause among developing countries is a foundational shock, as noted by Figueroa, which can be reinforced by climatic differences (Figueroa et al., 1996). This is typically a massive political event - for example, an invasion, followed by colonialism. In the case of Northern Ireland, for instance, the initial Protestant-Catholic inequalities were the outcome of a colonial experience, followed by the division of Ireland into an independent republic and a UK-controlled Northern Ireland; in the case of the US, the slave trade provided the foundational shock and in the case of Ghana, the north-south inequalities stem from colonial policy which favoured certain ethnic groups and regions, but also reflect climatic differences.

The next section of the chapter presents an empirical investigation into education in Peru, which illustrates and tests some of the hypotheses put forward here. 


\section{Evidence for the persistence and change of Hls}

A full investigation of why Hls persist should explore those that do not endure, as well as those that do. In this section, therefore, we examine some evidence of very persistent HIs (in Peru, Ghana and the United States), Hls that appear to have been reduced significantly (in Northern Ireland and Malaysia) and HIs that appear to have been reversed (Filipino and Japanese immigrants in the US). In each case we aim to explain developments according to elements in the framework advanced above.

\subsection{Education, labour markets and persistent inequality in Peru ${ }^{6}$}

Among heterogeneous societies in Latin America, the foundational shock of colonial invasion and settlements led to the emergence of very large Hls between indigenous peoples and the colonial settlers (Figueroa et al., 1996). Large inequalities in incomes and many other socioeconomic factors have persisted since this shock, paradoxically despite an expansion (and equalisation) in educational access. In the heterogenous society of Peru - made up indigenous people, mestizos, and whites persistent vertical inequality is a consequence, in large part, of persistent horizontal inequality.

For empirical analysis of development in Peru, groups were classified according to place of birth, although alternative criteria could have been used (for example, selfidentification or language) (Figueroa and Barron, 2005, justify this choice). It does not seem likely that the results would differ greatly with a different criterion.

The evidence shows persistent inequality in access to schooling. Both mean years of schooling and level of schooling show strong inequalities, with the W group most favoured, followed by the $\mathrm{M}$ and then I (Table 1).

Table 1: Educational inequality in Peru, 2003

\begin{tabular}{lccc} 
& Whites & Mestizos & Indigenous \\
\hline Mean years of schooling & 14 & 11 & 7 \\
$\begin{array}{l}\text { Proportion with post- } \\
\text { secondary education, } \%\end{array}$ & 70 & 36 & 15 \\
\hline
\end{tabular}

Evidence on the returns to education show that wages and salaries are positively related to the level of education attained, as predicted by 'human capital' theory. But in a heterogeneous society, there may be differences in returns according to group, as argued above, because of differences in school quality, learning environment and social capital, as well as discrimination. Statistical analysis shows significant differences in the returns to education across groups in Peru (see Figure 3 below). Thus mean incomes for those completing primary education are 800 soles per month for whites, 700 for mestizos and 600 for indigenous. These differences in returns to education imply that even as deprived groups catch up with more privileged groups in educational access, they still fall behind in incomes. This is supported by data showing some educational catch-up in quantitative terms, but large gaps in incomes. Educational catch-up can be shown by comparing education achieved across generations. Thus among Whites, average years of education attained by people aged 25-34 in 2003 were 17 per cent higher than those aged 55-64, among the Mestizos years of education rose by a third, but among the Indigenous group the

\footnotetext{
${ }^{6}$ This section is taken from Figueroa 2006, which provides a much richer and fuller analysis.
} 
average years of education more than doubled. The ratio of Indigenous education years to Whites education years was 0.57 for all age groups in 2003. But the income gap was much higher, with a ratio of 0.28 of average Indigenous incomes to Whites incomes.

We hypothesise that the difference in returns to education are due to (i) persistent differences in the quality of education, due to inequalities in the quality of infrastructure across locations; (ii) persistent differences in the learning achievements of children across groups due to language issues and differences in learning environments in the home; and (iii) overt or implicit discrimination. On top of the still highly unequal access to education (despite some catch-up), this leads to large inequalities in incomes.

Figure 3: Interethnic differences in returns to education in Peru

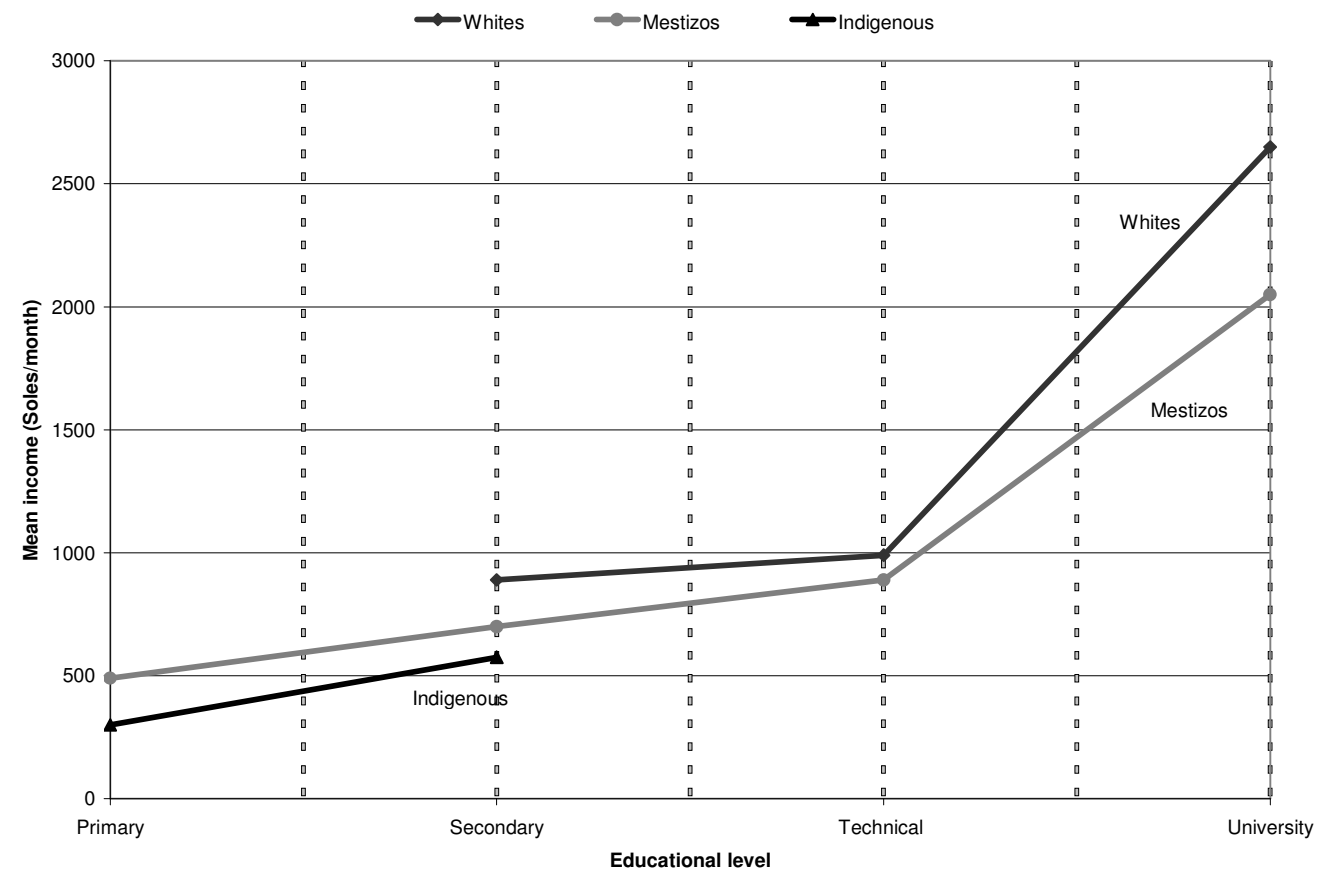

Source: Figueroa (2006).

\subsection{North-south inequalities in Ghana}

Like several other West African countries (for example, Côte d'lvoire, Togo, Benin and Nigeria), Ghana is confronted with a severe developmental north-south gap. Regional inequalities are important types of $\mathrm{HI}$ in themselves, since they can give rise to separatist movements. Moreover, in many cases (including that of Ghana) they overlap closely with ethnic differences and are also associated with religious differences. Ghana's current regional inequalities arise from a combination of circumstances and policies. Three important factors can be identified in this respect: first, the geographical concentration of most marketable agricultural activities/resources, particularly tree crops such as cocoa, as well as natural resources, notably minerals and forest resources, in the southern regions. Due to scant and irregular rainfall, most of the crops cultivated in the northern regions are subsistence crops. 
A second factor relates to the British colonial policy of investing more heavily in those regions where exploitable resources such as gold, diamonds, manganese, timber, and cocoa, were available or could readily be produced, and from where they could most cheaply be exported. Consequently, in addition to the administrative core region (the Greater Accra Region), the gold-rich regions (Ashanti and Western) and the cocoa-growing regions (Eastern, Central and Ashanti) received the bulk of the capital investments made during the colonial era.

A third factor relates to post-colonial investment patterns and economic policies. The Structural Adjustment Programmes (SAPs) especially, implemented from the mid1980s, reinforced the existing regional developmental inequalities. In particular, in line with the SAPs' objectives of restoring economic growth by rehabilitating Ghana's export economy, most external funding went to Ghana's 'industrial core region', the Greater Accra Region, as well as the cocoa, timber and mineral industries in the Western, Eastern, Ashanti and Brong Ahafo Regions (Songsore, 2003). Ghana's northern regions, in contrast, benefited very little from this renewed economic stimulus. However, in order to redress the economic exclusion of the northern regions and mitigate the developmental north-south divide, consecutive post-colonial regimes undertook specific projects in the northern regions, including the extension of the national electricity grid, the rehabilitation of the north-south roads, and greater expenditure on education.

Long-term data (Table 2) show the persistence of north-south differences. Indeed, in some respects inequalities have worsened since 1931. For instance, a comparison between the infant and child mortality rates in the northern and southern regions in 1931 and 1993 shows a worsening of north-south differences in relative terms. The 'Northern Territories' of what was then called Gold Coast correspond broadly to Ghana's three current northern regions (i.e. Northern, Upper West and Upper East Regions). Infant and child mortality rates of the Northern Territories in then Gold Coast were considerably closer to the national average than they are in contemporary Ghana. This confirms the unequal development progress made by the northern regions compared to the southern regions over the six decades. 
Table 2: Infant/child mortality rates for 1931 and 1993

\begin{tabular}{l|llll}
\hline Gold Coast, 1931 & \multicolumn{2}{|l}{ Absolute mortality } & rates, per 1000 & \multicolumn{2}{l}{ Relative to national average } \\
& Infant mortality & Child mortality & Infant mortality & Child mortality \\
\hline Eastern Province, Colony & 159 & 161 & 0.93 & 0.70 \\
Central Province, Colony & 171 & 283 & 1.00 & 1.23 \\
Western Province, Colony & 148 & 311 & 0.87 & 1.36 \\
Ashanti & 145 & 240 & 0.85 & 1.05 \\
Northern Territories & 214 & 248 & 1.26 & 1.09 \\
National average & 171 & 229 & 1.00 & 1.00 \\
\hline Ghana, 1993 & Absolute mortality rates & Relative to national average \\
& Infant mortality & Child mortality & 1 Infant mortality & Child mortality \\
\hline Western Region & 76 & 60 & 1.15 & 1.05 \\
Central Region & 72 & 61 & 1.09 & 1.07 \\
Greater Accra Region & 58 & 44 & 0.88 & 0.77 \\
Volta Region & 79 & 42 & 1.20 & 0.74 \\
Eastern Region & 56 & 40 & 0.85 & 0.70 \\
Ashanti Region & 65 & 34 & 0.98 & 0.60 \\
Brong Ahafo Region & 49 & 48 & 0.74 & 0.84 \\
Northern Region & 114 & 139 & 1.73 & 2.44 \\
Upper West Region & 85 & 113 & 1.29 & 1.98 \\
Upper East Region & 105 & 84 & 1.59 & 1.47 \\
National average & 66 & 57 & 1.00 & 1.00 \\
\hline
\end{tabular}

Source: Gold Coast figures are calculated from the 1931 Census. The 1993 mortality rates are drawn from the 1997 Ghana Human Development Report.

1) The child mortality rate for 1931 differs somewhat from the conventional definition as it is based on the number of children that died before reaching puberty rather than under the age of five.

Despite specific measures taken to correct north-south inequalities in recent years, Ghana's socioeconomic north-south divide remains severe - and has in some respects worsened - as illustrated by Table 3. 
Table 3: Socioeconomic inequalities across Ghana's regions in the 1990s

\begin{tabular}{|c|c|c|c|c|c|c|}
\hline & \multicolumn{2}{|c|}{$\begin{array}{l}\text { Incidence of } \\
\text { poverty }(\%)^{\mathrm{a}}\end{array}$} & \multicolumn{2}{|c|}{$\begin{array}{l}\text { Literacy } \\
(\% \text { literate })^{b}\end{array}$} & \multirow{2}{*}{$\begin{array}{l}\begin{array}{l}\text { Access to health } \\
\text { services }(\%)^{c}\end{array} \\
1997\end{array}$} & \multirow{2}{*}{$\begin{array}{l}\begin{array}{l}\text { Primary school } \\
\text { enrolment }(\%)^{d}\end{array} \\
1997\end{array}$} \\
\hline & 1992 & 1999 & 1993 & 1998 & & \\
\hline Western & 60 & 27 & 37 & 54 & 28 & 75 \\
\hline Central & 44 & 48 & 43 & 55 & 36 & 72 \\
\hline Greater Accra & 26 & 5 & 60 & 76 & 78 & 70 \\
\hline Volta & 57 & 38 & 46 & 58 & 42 & 70 \\
\hline Eastern & 48 & 44 & 46 & 66 & 33 & 78 \\
\hline Ashanti & 41 & 28 & 31 & 64 & 43 & 72 \\
\hline Brong Ahafo & 65 & 36 & 30 & 53 & 32 & 72 \\
\hline Northern & 63 & 69 & 8 & 13 & 18 & 40 \\
\hline Upper West & 88 & 84 & 12 & 20 & 8 & 45 \\
\hline Upper East & 67 & 88 & 8 & 20 & 20 & 36 \\
\hline National & 52 & 40 & 34 & 51 & 37 & 67 \\
\hline
\end{tabular}

a) Data drawn from Songsore (2003). The poverty line was the same in both years, i.e. $\$ 900,000$ per adult per year.

b) Authors' calculations based on data from the 1993 and 1998 Demographic and Health Surveys.

c) and d) Data drawn from the 1997 Ghana Core Welfare Indicators Survey.

With respect to poverty incidence, the north-south divide widened during the 1990s: while the overall incidence of poverty decreased from 52 per cent to 40 per cent in the period 1992-99, two of three northern regions (the Northern and Upper East regions) actually witnessed an increase in the incidence of poverty. However, it appears that the northern regions were able to catch up slightly with the southern regions on literacy.

The theoretical insights developed earlier prove helpful for understanding the emergence and persistence of the socioeconomic inequalities between Ghana's northern and southern regions. Thus the initial north-south inequalities emerged as a result of the combined effect of the colonial 'shock' and prevailing climatic/ecological differences. Subsequently, the educational programmes aimed at increasing the level of education in the northern regions, undertaken by consecutive Ghanaian governments since independence in 1957, had limited success in reducing the developmental inequalities between Ghana's north and south, supporting the view that increases in human capital alone, without corresponding increases in financial and social capital, are insufficient to kick-start development and reduce Hls. In the case of Ghana, the impact of adjustment policies was to reinforce the advantage of the south as against the north, making it especially difficult for the educated to find good productive opportunities and leading to an out-migration to the south. The north received less than 1 per cent of direct foreign investment. Thirdly, the lack of political mobilisation of the 'north' as a whole makes more extensive and comprehensive redistribution and development initiatives highly unlikely. On the one hand, the northern political elites appear to be content to live with the prevailing north-south inequalities as long as they themselves have access to the state's patronage networks. On the other hand, and arguably more importantly, the (re-)occurrence of several serious inter- and intra-ethnic conflicts in the northern regions - for example, the 1994 Konkomba war and 2002 Dagbon crisis, themselves related to Hls within the north - has not only resulted in the destruction of political as well as social capital, but it also makes mobilisation for mutual benefit less likely. 
Migration from the northern regions to the southern regions has improved the socioeconomic situation of some migrants, but it has not led to a significant reduction in north-south inequalities (for example, through the transfer of funds to family members left behind), partly because most northern migrants are among the poorest section of the population in the southern regions.

\subsection{Black/white inequalities in the United States}

The racial inequalities in the United States have their origins in 300 years of economic, physical, legal, cultural and political discrimination based on race, with slavery as the foundational shock which initiated the persistent inequalities. Blacks and whites not only differ substantially in 'objective' socioeconomic terms, but also have very different perceptions of the basic causes of these inequalities. Based on the 1996 General Social Survey, Smith and Seltzer (2000: 34) note that 'there is a tendency for blacks to blame racism for their lower status in America, whereas whites tend to blame blacks themselves.' For instance, while 64 per cent of the blacks in this survey saw 'past discrimination' as a major cause of black inequality, only 35 per cent of the whites had a similar view.

Although it is mostly acknowledged that some progress has been made in reducing racial economic inequalities, there is an abundance of evidence showing persistently large income and wealth gaps between blacks and whites. In 2001, for instance, 'the real median income of black families was only about 62 percent of that of Whites, only 10 percent higher than it was in 1947 when the ratio was 52 percent' (Brown et al., 2005: 13). In absolute terms, the black-white real median income gap doubled from $\$ 10,386$ to $\$ 20,469$ in the period from 1947 to 2001 (Brown et al., 2005: 13).

Table 4: Wealth by income and race

\begin{tabular}{l|ll|ll|ll}
\hline & \multicolumn{2}{|l|}{ White } & & \multicolumn{2}{l|}{ Black } & \multicolumn{2}{l}{ Black/White ratio $^{{ }^{2}}$} \\
& NW & NFA & NW & NFA & NW & NFA \\
\hline Highest fifth median & 133,607 & 40,465 & 43,806 & 7,448 & 0.33 & 0.18 \\
Second-highest median & 65,998 & 13,362 & 29,851 & 2,699 & 0.45 & 0.20 \\
Middle fifth median & 50,350 & 6,800 & 14,902 & 800 & 0.30 & 0.12 \\
Second-lowest median & 39,908 & 3,599 & 6,879 & 249 & 0.17 & 0.07 \\
Lowest fifth median & 17,066 & 7,400 & 2,400 & 100 & 0.14 & 0.01
\end{tabular}

Note: NW = net worth; NFA = net financial assets.

a) Our calculation based on Shapiro and Kenty-Drane's (2005) data.

Source: Shapiro and Kenty-Drane (2005: 177).

Racial inequalities in wealth and financial assets are even more pronounced than inequalities in family incomes. According to Shapiro and Kenty-Drane (2005), in 1999, the black-white wealth-gap ratio was 0.10, with typical white households having an overall median net worth of nearly $\$ 81,450$ and blacks a median of just $\$ 8,000$. The black-white financial assets-gap ratio was even lower, at 0.09 . While the median net financial assets of white families in 1999 was $\$ 33,500$, the median black family possessed just $\$ 3,000$. This severe wealth disparity exists even between blacks and whites in the top 20 per cent category of income earners (see Table 4). Shapiro and Kenty-Drane (2005) stress the importance of socio-historical legacies, particularly slavery, as well as ongoing residential segregation in accounting for modern-day wealth inequality between blacks and whites. Although the 1968 Fair 
Housing Act outlawed housing discrimination, blacks are far more likely to live in segregated neighbourhoods than either Asian Americans or Latinos (Massey and Denton, 1993).

Furthermore, as Brown et al. (2005: 14) note, 'blacks are much less likely to own a home, and when they can get a mortgage, they receive far less favourable terms than do comparable whites.' Keister (2000: 219) further notes that 'opportunities to invest [and therefore returns to capital and wealth accumulation] vary systematically because income varies systematically by race and affects ability to save.' Another factor which has been shown to affect racial income and wealth inequalities is differences in educational opportunities (see for example Keister, 2000).

Table 5: College attendance and completion by race, person 25 or older, 1960-1995

\begin{tabular}{llrl} 
& \multicolumn{1}{l}{ Black } & White & Black/White Ratio \\
\hline & \multicolumn{1}{l}{ Percent who attended college } & \\
1960 & 7.2 & 17.4 & 0.41 \\
1970 & 10.3 & 22.4 & 0.46 \\
1980 & 21.9 & 33.1 & 0.66 \\
1995 & 37.5 & 49.0 & 0.76 \\
& Percent with 4 or more years of college \\
1960 & 3.1 & 8.1 & \\
1970 & 4.4 & 11.3 & 0.38 \\
1980 & 8.4 & 17.1 & 0.39 \\
1995 & 13.2 & 24.0 & 0.49 \\
\hline
\end{tabular}

Source: Thernstrom and Thernstrom (1997: 192).

The average educational attainment of black and white persons aged between 25 and 29 did converge significantly between 1940-82: while blacks completed around three and a half fewer years of school than whites in 1940, the difference had decreased to about two years in 1960 and to about half a year in 1982 (Farley, 1984).

Nonetheless, racial disparities persist at the highest level of educational attainment in modern-day US. Although the black-white gap in college attendance (Table 5) narrowed in the period 1960-95, there continues to be a significant difference in the proportion of blacks and whites with a college degree. In 1995, blacks were only 55 per cent as likely as whites to have attended four or more years of college.

Finally, when it comes to racial disparities in access to health services and outcomes a somewhat mixed picture emerges. There has been some narrowing in access, but persistent, and for some indicators widening, inequalities in outcomes. Although the adoption of Medicare and Medicaid has contributed to a significant reduction in racial differences in the use of health-care facilities, 'racial differences for many health indicators remained unchanged or in some cases widened' (Brown et al, 2005: 14). While black infant mortality rates dropped by half between 1960 and 1980, the ratio of black-white infant mortality rose from 1.94 in 1980 to 2.35 in 1998 (Brown et al, 2005: 14). Brown et al. (2005: 14) conclude that: ' $\ldots$, neither the civil rights revolution nor diminishing prejudice have made much difference to racial disparities in mortality, the most fundamental matter of health. Neither income nor poverty status alone can explain these racial differences.' 
The persistence of black inequality in the US exemplifies several of the factors identified in the theoretical framework. In the US, slavery was the obvious foundational shock which lies at the heart of the racial inequalities. The period of slavery and then the period of institutionalised racial discrimination and oppression, lasting until the emergence of the civil rights movement in the 1960s, caused severe educational, income, wealth and health disadvantages for the black population. Despite 30 years of affirmative action programmes which followed and which contributed to a significant reduction in racial inequalities in education, persistently large gaps between blacks and whites continued in almost all economic, social and health indicators and measures. Inequalities in some health indicators (for example, infant mortality rates) even widened during the last two decades. This persistence in inequality arose because historic discrimination and disadvantages not only resulted in lower levels of human, financial and social capital for the black population, but also (indirectly) in lower returns to these different types of capital. For example, poor black families are currently either unable to secure a mortgage loan because they cannot contribute funds of their own, or, if they do get a mortgage, they are charged higher interest rates, which means lower returns to their investment, while neighbourhood effects have been shown to handicap blacks in educational and employment opportunities. Achieving a significant reduction in racial wealth inequalities is therefore proving extremely difficult, even though affirmative action programmes have contributed to increasing the human capital stock of the black population.

\subsection{Protestant/Catholic inequalities in Northern Ireland}

'The origins of economic inequality lie in the seventeenth century when it was created as a matter of government policy. ... Protestants were in firm control of Northern Ireland's economic resources from partition [1921] until the 1960s. They were dominant at all levels of the private sector including the crucial areas of industry and finance. They controlled the apparatus of state and - within the limits of Northern Ireland's delegated powers - public policy at regional and local levels. They were the dominant presence in the major agricultural and business organisations, professional associations and influential informal networks. They had higher levels of education and training than Catholics' (Ruane and Todd, 1996: 153, 171).

The limited evidence available shows that systematic inequalities in many dimensions persisted for the first three-quarters of the $20^{\text {th }}$ century. For example, a study of occupational mobility in Belfast, 1901 to 1951, shows no narrowing of the gap, with the Catholics disfavoured at every level (Hepburn, 1983), with fewer Catholics moving upwards from manual to non-manual occupations from 1901 to 1951 than Protestants, and more Catholics than Protestants moving downwards. For the 1970s, Miller (1983) found that the initial disadvantage of Catholics worsened further across generations. The unemployment rate among Catholics remained consistently above that of Protestants during most of the twentieth century. The Catholic unemployment rate was 2.6 times the Protestant one in 1917 and the same in 1971 (McGarry and O'Leary, 1995).

The Catholics were systematically and consistently underrepresented in the higher echelons of the civil service. In 1927, 6 per cent of 'staff officers' were Catholic (while the Catholic share of population was about 30 per cent); in 1959, the proportion was still 6 per cent in 1943, 5.8 per cent; and in 1971, 11 per cent of senior public officials were Catholic (while their share of population was then 31 per cent) (Whyte, 1987). Catholics were also severely underrepresented in the police force (the Royal Ulster Constabulary-RUC), accounting for only 17 per cent of the police force in 1936, 12 per cent in 1961 and 11 per cent in 1969. 
In education, Henry VIII established Protestant English-speaking schools throughout Ireland and forbad Catholic and vernacular ones in the $16^{\text {th }}$ century. Catholic schools were allowed from 1812 and segregated education developed. However, data shows Catholic disadvantage in admission to grammar schools and $\mathrm{O}$ and A-level achievements up to the mid-1970s. Other indicators of inequality were the higher proportion of Catholics on income support (37 per cent compared with 20 per cent among Protestants in the mid-1980s), and the poorer housing conditions. In 1971, for example, 29.3 per cent of Catholics had a housing density of more than one person per room compared with 9.8 per cent of Protestants.

There were also sharp political inequalities. One of the first changes made after partition was to abolish the proportional representation system, followed by the redrawing of boundaries. Buckland (1979) shows that 'The 'sole concern' of the Ministry of Home Affairs was 'how to give effect to the views of the Unionist [Protestant] rank and file' (quoted in Whyte, 1983). Given the numerical majority of the Protestants, the majoritarian voting system and redrawn boundaries assured the Protestant community permanent power.

The disadvantage of the Catholics again illustrates many of the factors identified in the earlier theoretical discussion. First, there was a foundational shock, represented by the British assumption of power and the immigration of people from Britain who took the best land and dominated official employment. Secondly, severe educational disadvantage occurred. Thirdly, there was sustained discrimination in employment, with cumulative impact via informal networks: 'The informal networks which are still so powerful in Northern Ireland and through which so much employment is found, operate to maintain and reinforce employment patterns already established... even if there were never in Northern Ireland a single instance of individual discrimination in the future, the patterns laid down will remain much the same' (Murray and Darby, 1980: 5, quoted in Whyte, 1983). This illustrates the importance of asymmetrical social capital. Because of this discrimination and other handicaps, Catholics attained lower returns to education, an estimated increase in incomes of $\$ 159$ for each extra year of schooling, compared with $\$ 254$ for Protestants (Covello and Ashby, 1980), and Catholics were less likely to find jobs than Protestants for any given level of education (Cormack et. al., 1980). An investigation into Catholic-Protestant differences in mean income for 1989 and 1990 among employees found that this 'could entirely be explained in terms of different rates of reward attached to a given set of labour market characteristics' (Borooah et al., 1995: 41). 
Figure 4: The evolution of horizontal inequalities in Northern Ireland

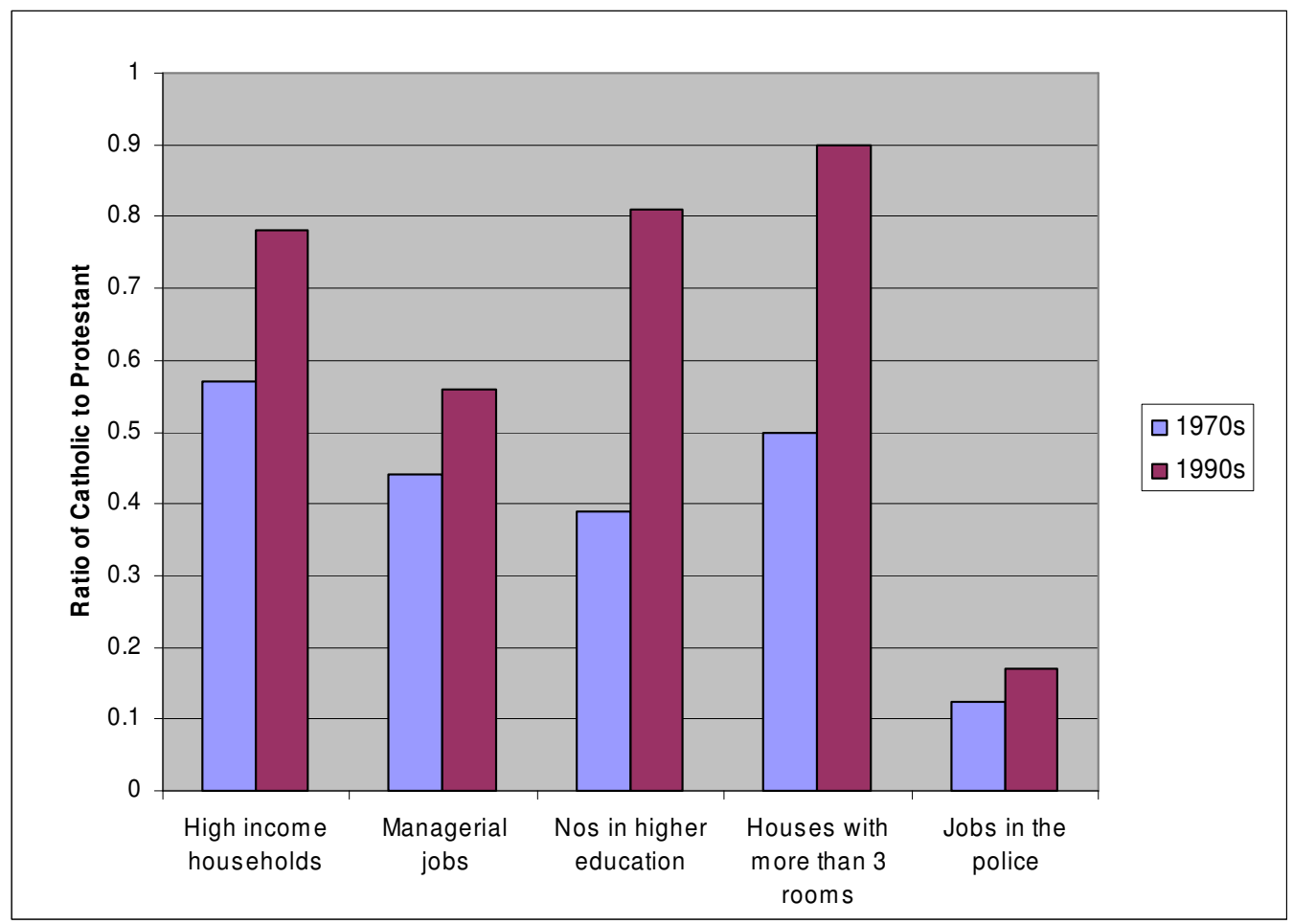

Source: Cain Web service

From the mid-1970s, however, UK and EU policy aimed to eliminate these inequalities, and they succeeded to a remarkable extent (see Figure 4 above). For instance, Catholics caught up significantly with Protestants in university education and the share of managerial positions, so that very little disadvantage remained (the proportion of managers and administrators who are Catholic rose from 30.5 per cent in 1971 to 35.8 per cent in 1997) (Fair Employment Commission, 1997, Monitoring Report No. 8). Catholic housing conditions also improved considerably so that they were almost equivalent to Protestant conditions in terms of the availability of a bath/shower and an inside toilet, and better in terms of the availability of central heating (Melaugh, 1994). Breen (2000) found a much diminished net advantage of Protestants in employment over the period 1973-1996.

However, some disadvantage remained. For example, Protestants were still overrepresented in the 40 largest companies (with 1.6 times the employment, while being 1.2 times the population size, in 1997) and a higher proportion of Catholics remained on income support. Further, a government survey in 2004 on inequality in health and social care found that Catholics were significantly disadvantaged in each area reported on. In particular, it was reported that Catholics were 10-19 per cent more disadvantaged regarding standardised mortality rates, 10-19 per cent regarding immunisation rates, over 20 per cent on dental registrations and over 20 per cent with regard to hospital admissions (McWhirter, 2004). 


\subsection{Malay/Chinese inequalities in Malaysia}

In Malaysia, the bumiputera (an umbrella term for indigenous groups), who account for the majority of Malaysia's population, were at a severe economic disadvantage vis-à-vis the Chinese when the country became independent in 1957, leading to a potentially explosive situation. But systematic affirmative action has successfully diffused this tension. A total of 62 per cent of Malaysians are bumiputera, 30 per cent are ethnic Chinese and 8 per cent are Indians. At independence, economic and social Hls systematically favoured the Chinese: for example, bumiputera household incomes were less than half those of the Chinese, they accounted for only 8 per cent of registered professionals, less than 2 per cent of ownership of capital on the stock exchange and their educational enrolment rates were lower at each level of education (see Figure 5).

Figure 5: The evolution of different horizontal inequality indicators in Malaysia, 1970-90

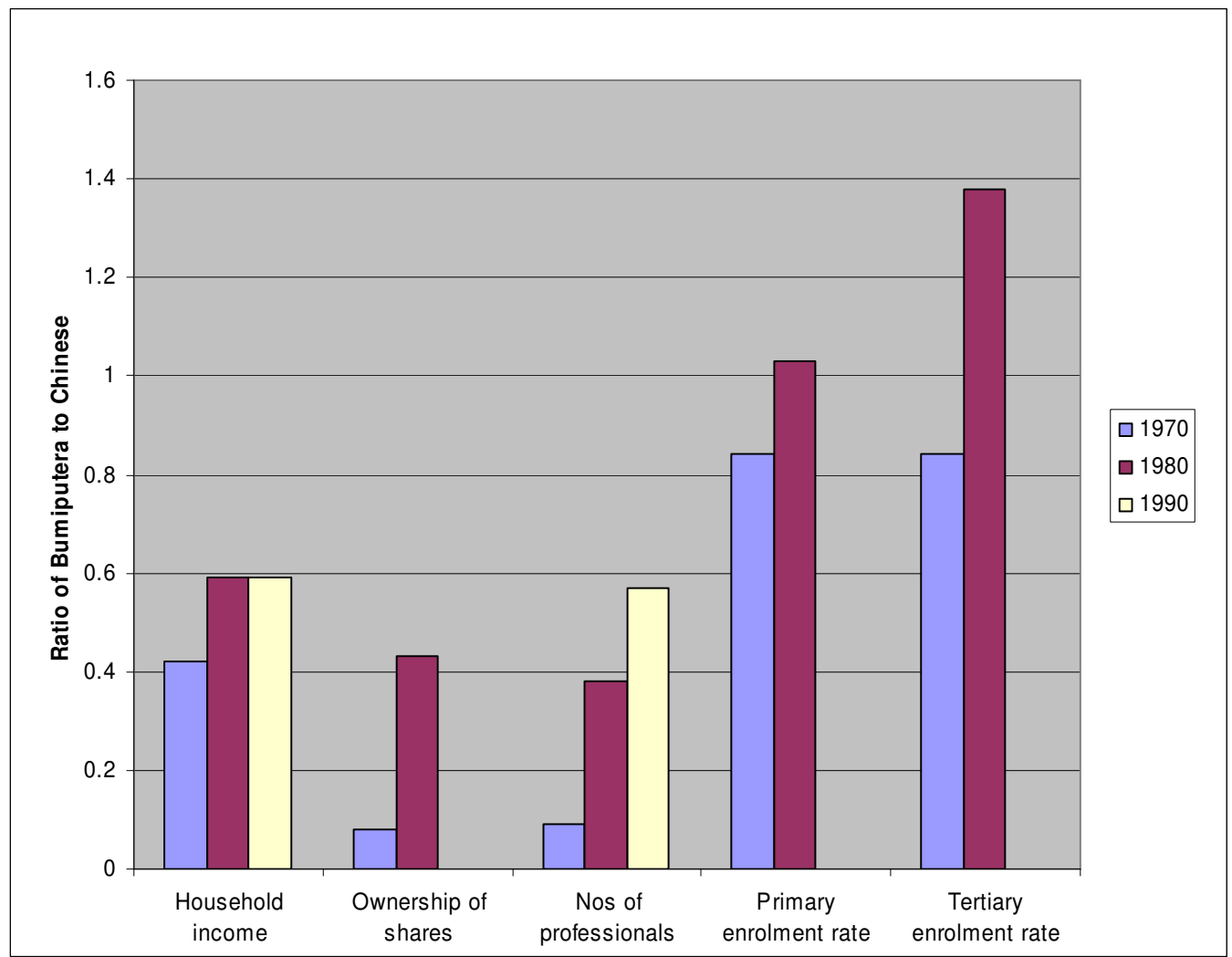

Source: Stewart (2002)

The economic disadvantage of the Malay community has its origins in the colonial period. Under British colonial rule, the method of production was organised into two distinct and parallel types which was complemented by an 'ethnic division of labour' (see Faaland et al., 2003; Abraham, 1997; and Brown, 1997). As Faaland et al. (2003: 7) note: 'The Europeans, the Chinese and the Indians were mostly engaged in the high productivity modern sector of the economy, as entrepreneurs, managers and employees in firms, estates and trading companies, while the Malays were mostly engaged in the low productivity traditional sector of peasant agriculture and fishing.' 
By the mid-twentieth century, the colonial legacy of 'ethnic division of labour' led to a situation in which the Chinese dominated the economy, while the numerically dominant Malay community was severely economically disadvantaged (Brown, 2005). In 1967, for instance, the average income in absolute terms was approximately $\$ 3,000$ for non-Malays compared to about $\$ 1,750$ for Malays (Faaland et al., 2003: 62).

When Malaya gained independence from the British in 1957, the Malays and nonMalays came to "the notorious independence "bargain" of "Politics for the Malays, Economy for the Chinese"' (Case, 1996 quoted in Brown, 2005). However, "by the late 1960s, many Malays were increasingly dissatisfied with their side of the bargain, a dissatisfaction expressed by the new breed of Malay ultras' (Brown, 2005: 4; original emphasis). After the May 1969 general election descended into ethnic rioting, the government identified the severe economic inequalities between the Malays and Chinese as the major cause of the emergence of ethnic violence and introduced an ambitious and comprehensive redistribution policy, the New Economic Policy (NEP). The NEP was aimed at creating the socioeconomic conditions for national unity through reducing poverty and interethnic economic disparities, especially between the indigenous Bumiputeras (mainly Malays, especially in peninsular Malaysia) and non-Bumiputeras (mainly Chinese and Indian Malaysians).' (Jomo, 1990: 469)

The NEP is arguably the most successful ethnic inequality-reducing programme implemented by a developing country. Policies that followed included quotas, targets and affirmative action with respect to education, land ownership, public service employment and ownership of quoted companies. The policies were undoubtedly successful. The proportion of bumiputera professionals rose from 8 per cent to 54 per cent; bumiputera students in tertiary education increased from 43 per cent to 54 per cent of the total, and there was a similar improvement at other levels of education. The share of corporate stock ownership rose from 1.5 per cent in 1969 to 20.6 per cent in 1995 (see Figure 5 above). While bumiputeras retained their dominant position in agriculture, there was an economy wide switch out of agriculture into manufacturing and services, and the bumiputera position in these sectors improved significantly.

Although the NEP led to a drastic reduction in the Malay-Chinese income inequalities, severe income differences persist. This point is illustrated by Figure 6, which depicts the evolution of two measures of horizontal inequality in Malaysia over the period since the inception of the NEP in 1970 (Brown, 2005) ${ }^{7}$. Both measures show considerable reductions in inequality.

\footnotetext{
${ }^{7}$ The first measure is a simple unweighted ratio of Chinese to Malay average household income and the second measure is a population-weighted standard deviation of group incomes from the national mean. Both measures are indexed to 1970.
} 
Figure 6: The evolution of income inequalities in Malaysia, 1970-2002

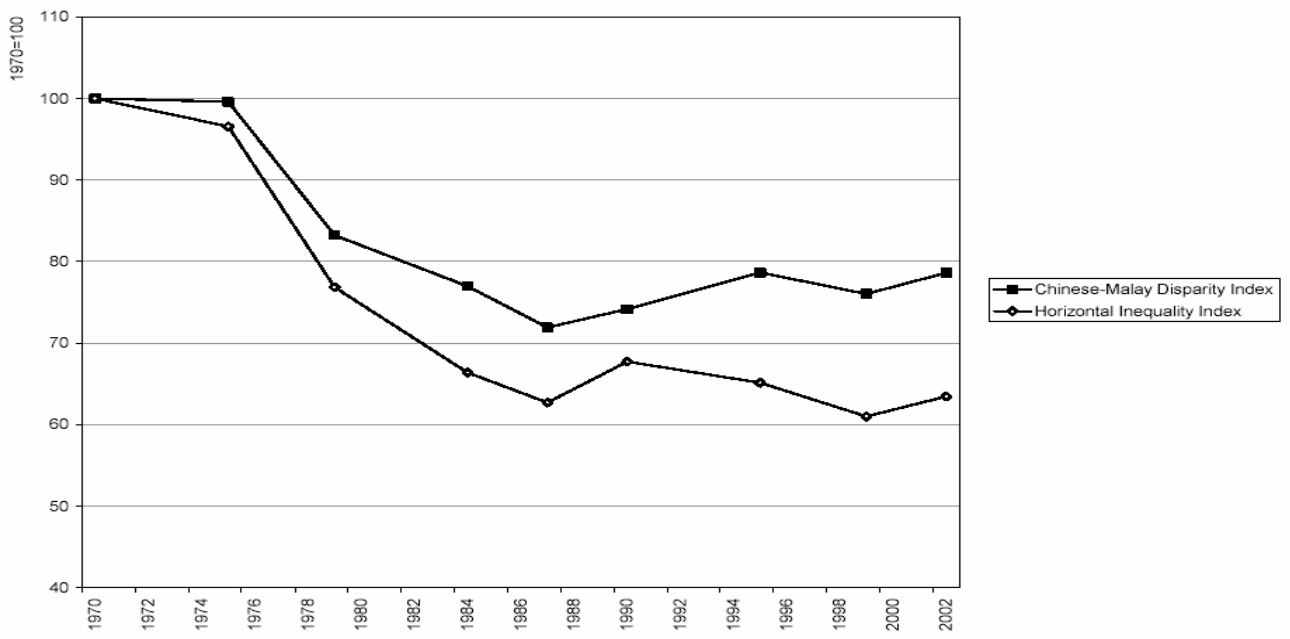

Source: Brown (2005: 2)

The affirmative action programmes did not impede growth, which was among the highest in the world in the post-colonial period (at 6.7 per cent p.a. from 1970 to 1990). Poverty fell dramatically from 49 per cent in 1970 to 7.5 per cent in 1999 and income distribution improved. Like the other countries considered here, the initial inequality was caused by the foundational shock of a colonial division of labour. But in this case deliberate policies to reverse the inequalities were successful, notably through simultaneous action towards education and economic opportunities. The political success of the NEP was indicated by the fact that during the economic crisis of 1997, when there were assaults on the Chinese in Indonesia, there were no such attacks in Malaysia.

\subsection{Japanese, Chinese and Filipino immigrants in the United States}

'Historically, different waves of Asian immigrants originating from different Asian countries have arrived in the United States at different times' (Pyong, 2006: 7). The Chinese were the first to move from Asia to the United States, especially California, between 1850 and 1882 . From the early 1880s, Japanese immigrants started arriving and around the turn of the century a large wave of Filipino immigrants migrated, initially to Hawaii and later the American mainland. However, as a result of government restrictions on Asian immigration, the proportion of Asian Americans in the US population remained insignificant in relation to the white, black and Latino populations until the late 1960s. Prominent laws aimed at curbing Asian immigration included: the Chinese Exclusion Act of 1882, the Asiatic Barred Zone provisions of the Immigration Act of 1917 and 1924, and the Tydings-McDuffie Act of 1934. However, following the introduction of the Immigration and Nationality Act of 1965, which abolished discrimination in immigration on national origin, Asian immigration increased dramatically. In particular, in the period 1965-2002, about 8.3 million Asian immigrants were admitted to the US, increasing their number from approximately 1.5 million or 1 per cent of the US population in 1970 to approximately 12 million or 4.2 per cent of the population in 2000. While the Japanese constituted the largest Asian immigrant group in 1970, the Chinese and Filipino communities were the two largest immigrant groups in 2000.8 Acknowledging the very substantial differences in the socio-economic progress of different Asian American communities, we focus here on

\footnotetext{
${ }^{8}$ This paragraph is based on Pyong (2006).
} 
arguably the three most successful Asian immigrant groups to date: Japanese, Chinese and Filipino.

Most Asian immigrants arriving from the late 1960s onwards tended to be highly educated due to the selective stipulations of the 1965 Immigration Act (Sakamoto and Xie, 2006), although there were some exceptions - for example, the Vietnamese. Moreover, there were known vacancies for the skills such migrants brought. Consequently, it is hardly surprising that their experience was much more successful than many other deprived or immigrant groups. Table 6 illustrates this point. All three Asian immigrant groups discussed here significantly improved their educational attainment position relative to the whites from 1960 to 1970, particularly with regard to the proportion of people of 25 years and older who had attended four or more years of college. From 1970-2000 they improved, or at least maintained, their higher levels of educational attainment relative to the US white population further. This contrasts with the evolution of the educational position of the black population, discussed earlier, which also got better, but started at much lower levels and improved less at the higher education levels, despite benefiting from affirmative action.

In addition to the positive impact of the high initial levels of education of the Asian immigrants as the offspring of more educated people tend to become more educated themselves,' group differences in norms and aspirations also appear to have played an important role. In particular, Asian Americans are often argued to have 'high aspirations and expectations for their children's economic success' (Sakamoto and Xie, 2006: 56). Correspondingly, '..., Asian American parents expect their children to achieve higher education than the parents of other racial groups' (Sakamoto and Xie, 2006: 58). Survey data confirm these different attitudes and expectations towards educational achievement among different groups. For instance, the 1988 National Educational Longitudinal Survey (NELS) found that 'over a third of the mothers and fathers of Asian $10^{\text {th }}$ graders expect their children to achieve some graduate education compared to less than a fifth of parents of whites' (Sakamoto and Xie, 2006: 58). Differences in attitudes towards education are also found among the children of different groups. The same study reported that over 20 per cent of the Asian $10^{\text {th }}$ graders aimed to get a Ph.D. compared to 14 per cent or less among the blacks, Hispanics and whites. It is reported that in order to achieve the goals that parents set for them and they set for themselves, Asian American children report doing, on average, close to one hour more of homework per week than do white children' (Sakamoto and Xie, 2006: 58). 
Table 6: The evolution of educational differences between whites, blacks and three Asian immigrant groups in the US, 1940-1990

\begin{tabular}{|c|c|c|c|c|c|c|c|}
\hline & 1940 & 1950 & $1960^{a}$ & 1970 & 1980 & 1990 & $2000^{b}$ \\
\hline & \multicolumn{7}{|c|}{$\begin{array}{l}\text { People of } 25 \text { years or older who completed at least } 4 \text { years of high school } \\
\text { (proportion relative to the whites, ratio) }\end{array}$} \\
\hline Blacks & 0.28 & 0.35 & 0.46 & 0.58 & 0.74 & 0.81 & 0.89 \\
\hline Japanese & 1.26 & 1.54 & 1.24 & 1.26 & 1.19 & 1.12 & 1.11 \\
\hline Chinese & 0.46 & 0.79 & 1.02 & 1.06 & 1.04 & 0.94 & 1.10 \\
\hline \multirow[t]{2}{*}{ Filipino } & 0.71 & 0.60 & 0.72 & 1.00 & 1.08 & 1.06 & 1.05 \\
\hline & \multicolumn{7}{|c|}{$\begin{array}{l}\text { Percent of people of } 25 \text { years or older who completed } 4 \text { or more years of college } \\
\text { (proportion relative to the whites, ratio) }\end{array}$} \\
\hline Blacks & 0.24 & 0.33 & 0.33 & 0.39 & 0.49 & 0.53 & 0.52 \\
\hline Japanese & 1.02 & 0.98 & 1.16 & 1.41 & 1.54 & 1.60 & 1.79 \\
\hline Chinese & 0.61 & 1.41 & 1.96 & 2.27 & 2.14 & 1.89 & 2.31 \\
\hline Filipino & 0.55 & 0.53 & 0.95 & 1.99 & 2.16 & 1.83 & 1.24 \\
\hline
\end{tabular}

Source: Authors' calculation based data drawn from various US censuses.

a) The 1960 figures are based on people of 14 years and older.

b) Data drawn from Sakamoto and Xie (2006).

Many of the highly educated Asian Americans who arrived after the 1965 Immigration Act also appear to have been able to convert their high levels of education into highstatus occupations and jobs. While during the first half of the century, 'Asians were concentrated at the bottom of the economic ladder, restricted to retailing, food service, menial service, and agricultural occupations', in modern-day America they are well represented in the 'well-paid, educated, white-collar sector of the workforce' (Espiritu, 1996: 65). For instance, Sakamoto and Xie (2006) show that 33 per cent of the male Asian Americans are employed as 'professionals' ('highly skilled occupations that typically require specialised training or licensed accreditation'), compared to 21 per cent of the whites and only 13 per cent of the African Americans. Although it is often claimed that Asian Americans are discriminated against when it comes to managerial-level positions, Sakamoto and Xie (2006) show that there is only a slight difference in managerial employment between whites and Asian Americans (8 per cent for whites versus 7 per cent for Asian Americans). The nativeborn Chinese population even has a slightly higher proportion (9 per cent) of 'managers.' 
Table 7: Average wages and earnings of male workers, 2000

\begin{tabular}{lll}
\hline Race/ethnicity & Wages $(\$ /$ hour $)$ & Earnings $(\$)$ \\
\hline Whites & 23 & 46,000 \\
Blacks & 18 & 30,000 \\
& & \\
Native-born Asians & & \\
All & 22 & 43,000 \\
Chinese & 28 & 56,000 \\
Japanese & 26 & 53,000 \\
Filipino & 19 & 33,000 \\
Korean & 21 & 40,000 \\
Asian Indian & 22 & 39,000 \\
Vietnamese & 15 & 24,000 \\
Other Asian & 17 & 30,000 \\
\hline
\end{tabular}

Source: Sakamoto and Xie (2006: 61)

Studies show that the income differentials between Asian Americans and whites have almost completely disappeared: in 2000, the average earnings of white individuals were approximately $\$ 46,000$, while native-born Asian Americans earned on average $\$ 43,000$. The average earnings of African Americans was substantially lower at only $\$ 30,000$ (Table 6). A similar picture emerges with regard to hourly wages. These aggregate figures for 'Asian Americans', however, disguise substantial differences in earnings between the different Asian American immigrant communities (see Table 6). For instance, while Korean $(\$ 40,000)$ and Vietnamese $(\$ 24,000)$ Americans earned on average considerably less than white Americans $(\$ 46,000)$, the Chinese $(\$ 56,000)$ and Japanese $(\$ 53,000)$ Americans earned substantially more than the whites. Although some authors such as Hirschman and Wong (1984), Feagin and Feagin (1993) and Espiritu (1996) conclude that Asian Americans suffer from 'racial' discrimination as their incomes are lower than they should be, given their (high) levels of education, a recent study by Sakamoto and Xie (2006) concludes that the bulk of the evidence indicates that most Asian Americans no longer face extensive or systematic racial discrimination in the contemporary American labor market.' Several other studies come to similar conclusions (see, for example, Xie and Goyette, 2004).

The example of Asian immigrants to the US shows that HIs do not necessarily persist. The factors that seem to explain the fact that Asian immigrant groups were able to 'catch up', as, indeed, European immigrants had earlier (Alba et al., 2001), are (i) their initially high levels of education; (ii) their group values, perhaps associated with these education levels, which led to high aspirations and strong group pressure for achievement in education and work - social capital and other group pressures were thus asymmetrically advantageous, rather than disadvantageous for these groups - and (iii) the fact that the selective immigration policies ensured that relatively highly paid jobs were available for most migrants. 


\section{Conclusions and policy implications}

This paper has presented theoretical reasons and some empirical evidence to suggest that socioeconomic Hls can be very persistent over time, in many cases lasting not just decades but centuries, often initiated by a foundational shock. In developing countries, colonialism and associated movements of people - not only from the imperial power, but also the movement of indentured labour from one part of the world to another - is the most important form of inequality-creating shock. Against the predictions of equilibrium neo-classical economics, where diminishing returns should equalise incomes over time, these initial inequalities have frequently persisted, sometimes narrowing but often remaining very large. This inequality is undesirable - because it traps people of certain ethnicities or races in relative poverty and powerlessness - and because it threatens political stability, since cultural difference provides a powerful potential mechanism of political mobilization. For both these reasons, Hls have a more adverse impact than $\mathrm{VI}$, of which they are one cause. Moreover, in some cases it is extremely difficult to reduce poverty without reducing HIs, since general anti-poverty measures will fail to take into account the special circumstances of deprived groups.

Our analysis suggests that group inequalities in various types of capital and in the returns to this capital initiate $\mathrm{HI}$, but this is often perpetuated by inequality of accumulation and by differential returns across groups, because the returns to any one type of capital are kept low by deficiencies in quantity and quality of other types of capital, as well as by past and current discrimination. The political system plays a central part because government policies can reinforce or offset other sources of inequality. The existence of political inequalities are then important in themselves because people mind about them and are more likely to mobilize, possibly violently, if they lack political power - and because domination of the political system is likely to determine whether there are policies that accentuate or diminish the other HIs.

However, sometimes groups do succeed in catching up - in the cases of Malaysia and Northern Ireland strongly supported by policy, and in the case of some Asian immigrant groups to the US, through their own efforts assisted by selective immigration policies. These 'success' stories provide insights on how Hls can be reduced over time.

Adopting the framework and using the examples discussed above, factors that help prevent persistent HIs, include:

- Processes that reduce the tightness of group boundaries, so that the salience of group membership falls and people can switch to more privileged groups, moving towards an equilibrium in which either group boundaries become invisible, or of no significance, or group inequalities are gradually eliminated. But we should note that, if only relatively few people can switch in this way (for example, 'pass' as whites), the situation of those left behind may become even worse, as they may consequently lack enterprising leaders. Thus to be effective there must be a genuine reduction in barriers to movement and/or salience of identity across the board. Reduction in the tightness of group boundaries is likely to be a product of norms, culture and changing social relations as much as explicit policies. For example, intermarriage, on a sufficient scale, can lead to a blurring of group boundaries, or even their disappearance - where, for example, are the once important differences between Angles and Saxons in modern-day Britain? Another example of a 
blurring of group boundaries is the merging of Javanese, Malay and Minangkabau identities into one 'Malay' identity in contemporary Malaysia. In addition, government policies are also relevant - for example, whether the government takes an integrationist or multicultural approach to difference, which informs its policy towards education and culture. Group and societal leaders play an important role in connection with the tightness of group boundaries, in constructing and accentuating difference. Here it is not so much whether or how the underprivileged groups mobilise, but more the attitudes of the privileged, because it is they who often accentuate difference in order to create barriers to entry. The media can have an independent as well as instrumental role in accentuating difference, or conversely, creating national unity.

- Processes that reduce inequalities in capital accumulation. Here policies towards reducing inequalities need to ensure that discrimination in loans, education admissions and so on is prohibited. But more is needed if past discrimination is to be offset. For example, unequal accumulation in the past will mean that any loan allocations requiring collateral discriminate against poor applicants. Similarly, educational admission policies based on competitive examination, or 'merit' will discriminate against children from uneducated backgrounds, those that do not speak the dominant language and so on. Hence it is usually necessary to go beyond out-ruling existing discriminatory practices to positive current discrimination (or affirmative action) in order to offset the disadvantages incurred by past discrimination.

- Processes to improve the returns to different types of capital. One requirement is to give simultaneous support to different types of capital accumulation in the deprived group, since investment in one type of capital alone may have little impact: for example, policies to extend education in Northern Ghana have little impact on the incomes of those who attend schools because they lack financial and social capital. A second requirement is to outlaw discrimination, and, as in the allocation of capital, to practise affirmative action as an offset to past discrimination, in employment. Thus fair employment legislation - which can make a substantial difference - may not be enough, and positive discrimination may be needed. There is some tension, however, between policies involving affirmative action and the objective of reducing the salience of group identities. Affirmative action, if carried out strictly on the basis of group identity - for example, policies favouring the bumiputera in Malaysia - will tend to accentuate further, not diminish, the salience of group boundaries. This impact could be lessened if the policies were framed in some other way - for example, on the basis of geography - but then they can be hijacked by the privileged group, as some have been in Northern Ghana, for example. Affirmative action on the basis of group identity may be the only way of overcoming deep-seated inequality, but its impact in reinforcing difference is a reason for aiming for a limited term for such policies.

- One important subset of policies to correct HIs over time are those directed at offsetting asymmetries in the quality of social capital. To do this, it is necessary to promote 'bridging' social capital for poorer groups so that more of their contacts are with the richer groups. However, this is not a matter of promoting any old contact; contacts which involve hierarchy (as in servant/master relationships) are not likely to generate effective social capital - people need to meet on roughly equal terms. There are a variety of ways 
that such bridging might be achieved: these include promoting mixed schools (for example, boarding schools containing members of all groups where groups are scattered regionally) and comprehensive schools plus bussing in areas where different groups live fairly close together; housing policies to promote mixed neighbourhoods; and encouragement of mixed civil society organisations.

Promoting inter-group contact, moreover, is not only likely to help reduce HIs but may also promote peace, following the 'contact' hypothesis, according to which more contact between groups is likely to reduce conflict (Amir, 1969; Hewstone \& Brown, 1986; Varshney, 2002). However, research indicates that not all contact improves relationships - indeed, some types of contact may enhance prejudice. In order for contact between members of different groups to reduce conflict, it seems that it needs to be contact on a near equal basis and to be cooperative rather than competitive (Hewstone and Brown 1986; Pettigrew, 1998).

While promoting bridging social capital may then improve the efficiency of social capital and contribute to reducing conflict, there is a question as to how far it should be at the expense of contacts within groups. 'Bonding' social capital is important too because formation of strong identity groups can assist in promoting self-respect of the group, as well as providing mutual insurance, and bargaining for an improved position for the group. Thus research into psychological wellbeing of African Americans found that 'environments that are segregated offer in-group support and acceptance, thereby protecting self-esteem against possible perils of rejection by a powerful out-group' Postmes and Branscombe 2002, p 735). Here too, as with affirmative action, it seems that there are some potential trade-offs. Enhancing bonding social capital may further embed identities, reduce the fluidity of group boundaries and, perhaps, reduce bridging type social capital (Fukuyama, 2001). Yet forming strong group cohesiveness, and using this for political and economic purposes, can be a more powerful and rapid way of improving the position of a deprived group than waiting for the slow impact of a 'melting pot'.

The examples of Northern Ireland and Malaysia, given above, show that policies can be effective in reducing long-term HIs substantially in a fairly short period. In both cases, the policies placed prime emphasis on human capital (improving the quantity and returns), but supported them by measures to improve the equity of economic opportunities. In the case of Northern Ireland, policies were primarily directed at fair employment (i.e. removing discrimination), and equal access to housing, education and health services. For the most part, the policies were geographically based, not explicitly according to group. Significant efforts were also made in Northern Ireland to improve inter-group contacts, via mixed schools and civil society associations (Niens \& Cairns, 2005). Yet identities have nonetheless remained clearly entrenched in Northern Ireland, with reports of more hostile interethnic attitudes in recent years. In Malaysia, the policies were directed at government employment, education and capital ownership, and were explicitly defined on the basis of group, reinforcing rather than reducing group differences. In Malaysia, there was an escalation in inter-group associations, but they proved ineffective in improving overall ethnic relations (Brown, 2004).

In contrast, some efforts were made to correct Hls in the cases of northern Ghanaians and blacks in the US, but they had a rather marginal impact, probably because they were not comprehensive enough - in each case focussing mainly on 
education, in a way that was insufficient to offset the legacy of previous discrimination and the handicaps imposed by deficiencies in other types of capital.

The role of politics is critical in explaining failures to combat socioeconomic HIs. The concerted efforts needed mean that the political system has to back the policy fully. This is likely to be the case where political HIs favour the deprived group, which happens in a democracy where this group forms the majority of the population, as in Malaysia. But where the political system is dominated by the more privileged group, as in Ghana and the US, then strong and comprehensive redistributory policies are less likely. Northern Ireland in the 1980s and 1990s was a special case, where the UK and EU determined policy, not the majority (privileged) Protestant population. But even where the deprived group forms the majority, it is difficult to combat high Hls in the context of strong opposition from the privileged groups. As some members of the deprived group gain elite positions (generally the potential leaders of the group), they too may be content to live with the HIs. The prevailing market philosophy also presents an obstacle since, while it favours less current discrimination, it disfavours affirmative action to offset the effects of past discrimination. Hence there are cases, like Nigeria and South Africa, where politics is dominated by the poorer group(s), but there is limited and ineffective action to correct the socioeconomic HIs. 


\section{References}

Abraham, C. E. R. 1997. Divide and Rule: The Roots of Race Relations in Malaysia. Petaling Jaya: Institute for Social Analysis.

Adato, M., Carter, M. and May, J. 2006. Exploring poverty traps and social exclusion in South Africa using qualitative and quantitative data. Journal of Development Studies 42 (2): 226-247.

Akerlof, G. A., and Kranton, R. E. 2000. Economics and Identity. The Quarterly Journal of Economics, 115 (3): 715-753.

Alba, R., Lutz A. and Vesselinov, E. 2001. How enduring were the inequalities among European immigrant groups in the United States. Demography 38 (3), 349-356.

Allen, T., and Eade, J. 1997. Anthropological approaches to ethnicity and conflict in Europe and beyond. International Journal on Minority and Group Rights 4: 217-246.

Amir, Y. 1969. Contact hypothesis in ethnic relations. Psychology Bulletin 71 (5): 319-342.

Anand, S. 1983. Inequality and Poverty in Malaysia: Measurement and Decomposition. New York: Oxford University Press.

Azariadis, C., and Drazen, A. 1990. Threshold externalities in economic development. Quarterly Journal of Economics 105 (2): 501-526.

Banerjee, A. V., and Newman, A. F. 1993. Occupational choice and the process of development. Journal of Political Economy 101: 274-298.

Banks, M. 1996. Ethnicity: Anthropological Constructions. London: Routledge.

Barrett, C. B., and Swallow, B. M. 2006. Fractal poverty traps. World Development 34 (1): 1-15.

Barrett, C., Marenya P. P., Mcpeak, J., Minten, B., Murithi, F., Oluoch-Kosura, W., Place, F., Randrianarisoa, J. C., Rasambainarivo, J., and Wangila, J. 2006. Welfare dynamics in rural Kenya and Madagascar. Journal of Development Studies 42 (2): 248-277.

Barrón Ayllón, M. Forthcoming. Horizontal Inequalities in Latin America: a Statistical Comparison of Bolivia, Guatemala and Peru. CRISE Working Paper No. 32. Oxford: Centre for Research on Inequality, Human Security and Ethnicity (CRISE), University of Oxford.

Behrman, J. R., 1990 The Action of Human Resources and Poverty on One Another: What We Have Yet to Learn. LSMS Working Paper No. 74. Washington: World Bank.

Black, S. E., Devereux, P. J., and Salvanes, K. G. 2005. Why the Apple Does Not Fall Far: Understanding intergenerational Transmission of Human Capital. The American Economic Review 95 (1): 437-450.

Blau, P. M. 1977. Inequality and heterogeneity: a primitive theory of social structure. New York: Free Press; London: Collier Macmillan. 
Blee, K. M., and Billings, D. B. 1996. Race differences in the origins and consequences of chronic poverty in rural Appalachia. Social Science History 20 (3): 345-373.

Borooah, V., McKee, P., Heaton, M., and Collins, G. 1995. Catholic-Protestant Income differences in Northern Ireland. Review of Income and Wealth 41 (1): 41-56.

Borjas, G. J. 1992. Ethnic capital and intergenerational mobility. The Quarterly Journal of Economics 107 (1): 123-150.

Borjas, G. J. 1995. Ethnicity, neighbourhood and human capital externalities. American Economic Review 85 (3): 365-390.

Breen, R. 2000. Class inequality and social mobility in Northern Ireland, 1973 to 1996. American Sociological Review 65 (3): 392-406.

Brooks-Gunn, J., Duncan, G., Klebanov, P., and Sealand, N. 1993. Do neighbourhoods influence child and adolsecent development? American Journal of Sociology 99 (2): 353-95.

Brown, G. 2005. Balancing the Risks of Corrective Surgery: The political economy of horizontal inequalities and the end of the New Economic Policy in Malaysia. CRISE Working Paper No. 20. Oxford: Centre for Research on Inequality, Human Security and Ethnicity (CRISE), University of Oxford.

Brown, G. 2004. Civil society and social movements in an ethnically divided society: The case of Malaysia, 1981-2001. Ph. D. thesis. School of Politics, University of Nottingham.

Brown, I. 1997. Economic Change in South-East Asia, c.1830-1980. Kuala Lumpur: Oxford University Press.

Brown, M. K., Carnoy, M., Currie, E., Duster, T., Oppenheimer, D. B., Shultz, M. M., and Wellman, D. 2005. The Myth of a Color Blind Society. Berkeley: University of California Press.

Brown, T. N., Williams, D. R., Jackson, J. S., Neighbours, H., Sellers, S., Myriam, T., and Brown, K. 1999. Being black and feeling blue: mental health consequences of racial discrimination. Race and Society 2 (2): 117-131.

Bourdieu, 1986. The forms of capital. In Richardson, J.G., ed., Handbook of Theory and Research for the Sociology of Education. New York: Greenwood Press.

Buckland, P. 1979. The Factory of Grievances: Devolved Government in Northern Ireland, 1921-1939. Dublin: Gill \& Macmillan.

Carter, M., and Barrett, C. B. 2006. The economics of poverty traps and persistent poverty: an asset based approach. Journal of Development Studies 42 (2) 178-199.

Chakraborty, S., and Das, M. 2005 Mortality, Human Capital and Persistent Inequality. Journal of Economic Growth 10(2): 159-190 
Cooper, S., Durlauf S., and Johnson P. 1994. On the evolution of economic status across generations. American Statistical Association, Business and Economic Section, Papers and Proceedings, 50-58.

Cormack, R., Osborne R., and Thompson, W. 1980. Work? Young school leavers and the structure of opportunity in Belfast. Belfast Fair Employment Agency, Research Paper No. 5.

Cormack, R. and Osborne, R.D., eds. 1983 Religion, Education and Employment: Aspects of Equal Opportunity in Northern Ireland, 64-77. Belfast: Appletree.

Corcoran, M. 1995. Rags to riches: poverty and mobility in the US. Annual Review of Sociology 21.

Corcoran, M., Gordon, R., Laren, D., and Solon, G. 1989. Effects of family and community background on men's economic status. NBER Working Paper No. 2896. Cambridge, MA: National Bureau of Economic Research.

Covello, V., and Ashby, J. 1980. Inequality in a divided society: an analysis of data from Northern Ireland. Sociological Focus 13 (2): 87-98.

Datcher, L. 1982. Effects of community and family background on achievement. Review of Economics and Statistics 64 (1). 32-41.

Devine, J.A., Plinkett, M., and Wright, J.D. 1992. The chronicity of poverty: evidence from PSID, 1968-1987. Social Forces 70 (3): 787-812.

Duncan, G. J., Gustafsson, B., Hauser, R., Schmauss, G., Messinger, H., Muffels, R., Nolan, B., and Ray, J. C. 1993. Poverty dynamics in eight countries. Journal of Population Economics 6 (3): 215-234.

Durlauf, S. N. 2002. Groups, social influences and inequality: a memberships theory perspective on poverty traps. SSRI Working Paper No. 2002-18. Madison, WI: Social Systems Research Institute, University of Wisconsin-Madison

Espiritu, L. Y. (1996). Asian American Women and Men. London: Sage Publications.

Faaland, J., Parkinson, J., and Saniman, R. 2003. Growth and Ethnic Inequality Malaysia's New Economic Policy. Kuala Lumpur: Utusan Publications \& Distributors Sdn Bhd.

Farley, R.. 1984. Blacks and Whites: Narrowing the Gap? Cambridge, MA: Harvard University Press.

Feagin, J., and Feagin, C. 1993. Racial and ethnic relations. $4^{\text {th }}$ ed. Englewood Cliffs, NJ: Prentice-Hall.

Figueroa, A., Altamariano, T., and Sulmont, D. 1996. Social exclusion and inequality in Peru. Geneva: International Labour Institute.

Figueroa, A., and Barron, M. 2005 Inequality, Ethnicity and Social Disorder in Peru, CRISE Working Paper No. 8. Oxford: Centre for Research on Inequality, Human Security and Ethnicity (CRISE), University of Oxford. 
Figueroa, A. 2006. Education, labour markets and inequality in Peru. Paper presented at the CRISE Latin America Workshop, Santa Cruz, Bolivia, September $18-20$.

Fukuyama, F. 2001. Social capital, civil society and development. Third World Quarterly 22 (1): 7-20.

Galor, O., and Zeira, J. 1993. Income distribution and macroeconomics. Review of Economic Studies 60 (1): 35-82.

Gurr, T. R., and Harff, B. 1994. Ethnic Conflict in World Politics. Oxford: Westview

Hepburn, A. C. 1983. Employment and Religion in Belfast, 1901-1951. In Cormack, R. J., and Osborne, R. D., eds, Religion, Education and Employment. Belfast: Appletree Press.

Hepburn, A. C.1983. Work, class and religion in Belfast, 1871-1911. Irish Economic and Social History 10: 33-50.

Hewstone, M., and Brown, R. 1986. Contact \& Conflict in Intergroup Encounters. Oxford: Basil Blackwell.

Hirschman, C., and Wong, M. 1984. Socioeconomic gains of Asian Americans, blacks and Hispanics: 1960-1976. American Journal of Sociology 90 (3): 584-607.

Horowitz, D. 1985. Ethnic Groups in Conflict. Berkeley, CA: University of California Press.

lisaaka, L., and Alenen, A. 2006. Social capital in Finland: domestic and international background. In lisaaka, L., ed., Social Capital in Finland - Statistical Review. Helsinki: Social Statistics Finland.

Jalan, J., and Ravallion, M. 2000. Is transient poverty different? Evidence for rural China. Journal of Development Studies 36 (6): 82-100.

Jomo, K. S. 1990. Whither Malaysia's New Economic Policy? Pacific Affairs 63(4): 469-499.

Jomo, K. S. 2001. Malaysia's New Economic Policy and 'National Unity'. Paper presented at the United Nations Research Institute for Social Development Conference on Racism and Public Policy, Durban, South Africa, September 3-5.

Jomo, K. S. 2004 The New Economic Policy and interethnic relations in Malaysia. Identities, Conflict and Cohesion Programme Paper No. 7. Geneva: United Nations Research Institute for Social Development (UNRISD).

Kanbur, R., and Zhang, X. 1999. Which regional inequality? The evolution of ruralurban and inland-coastal inequality in China from 1983 to 1995. Journal of Comparative Economics 27: 686-701.

Keister, L. A. 2000. Wealth in America: Trends in Wealth Inequality. Cambridge: Cambridge University Press. 
King, E. M., and Hill, M. A., eds. 1993. Women's Education in Developing Countries: Barriers, Benefits, and Policies. Baltimore and London: The Johns Hopkins University Press, published for the World Bank.

Krishna, A., Lumonya, D., Markiewicz, M., Mugumya, F., Kafuko, A., and Wegoye, J. 2006. Escaping poverty and becoming poor in 36 villages of Central and Western Uganda. Journal of Development Studies 42 (2): 322-345.

Loury, G. C. 1981. Intergenerational transfers and the distribution of earnings. Econometrica 49 (4): 843-867.

Loury, G. C. 2002. The Anatomy of Racial Inequality. Cambridge, MA: Harvard University Press.

Lundberg, S., and Startz, R. 1998. On the persistence of racial inequality. Journal of Labor Economics 16 (2): 292-323.

Majumdar, M., and Subramanian, S. 2001. Capability failure and group disparities: some evidence from India for the 1980s. Journal of Development Studies 37 (5): 104140.

Mancini, Luca. 2005. Horizontal inequalities and communal violence: Evidence from Indonesian districts. CRISE Working Paper No. 22. Oxford: Centre for Research on Inequality, Human Security and Ethnicity (CRISE), University of Oxford.

McGarry, J. and B. O'Leary 1995 Explaining Northern Ireland: Broken Images.

Oxford: Blackwells.

Mandal, S. 2004 Transethnic solidarities, racialisation and social equity. In Gomez, Edmund Terence, ed., The State of Malaysia: Ethnicity, equity and reform. London: RoutledgeCurzon

Massey, D., and Denton, N. 1993. American Apartheid: Segregation and the Making of the Underclass. Cambridge, MA: Harvard University Press.

McWhirter, L. 2004. Equality and inequalities in health and social care in Northern Ireland, A statistical overview. Belfast: Northern Ireland Department of Health, Social Services and Public Safety.

Melaugh, M. 1994. Majority Minority Review 3: Housing and Religion in Northern Ireland. Coleraine: Centre for the Study of Conflict, University of Ulster.

Miller, R. 1983. Religion and Occupational Mobility. In Cormack, R. J., and Osborne, R., eds, Religion, Education and Employment: Aspects of Equal Opportunity in Northern Ireland. Belfast: Appletree,

Mogues, T. and Carter, M. 2005. Social capital and the reproduction of economic inequality in polarised societies. Journal of Economic Inequality 3: 193-219.

Murray, D., and J. Darby. 1980. The vocational aspirations and expectations of school leavers in Londonderry and Strabane. Fair Employment Agency Research Paper No. 6. Belfast: Fair Employment Agency 
Niens, U., and Cairns, E. 2005. Conflict, contact and education in Northern Ireland. Theory into Practice 4 (44): 337-344.

Nik Azis, N. P. 2003. Education and Nation-Building: The Malaysian Experience. In Gomez, E. T. and Stephens, R., eds, The State, Economic Development and Ethnic Co-Existence in Malaysia and New Zealand. Kuala Lumpur: University of Malaysia.

Noorbakhsh, F. 2005. Spatial inequality and its dimension in Iran: empirical evidence. Oxford Development Studies 33 (3 and 4): 473-491.

Nurmela, J. 2006. Does the use of communication media add to social capital? In lisaaka, L., ed., Social Capital in Finland - Statistical Review. Helsinki: Social Statistics Finland.

Østby, G. 2003. Horizontal Inequalities and Civil War. Oslo: Norwegian University of Science and Technology.

Pettigrew, T. F. 1998. Intergroup contact theory. Annual Review of Psychology 49: 65-85.

Papatheodorou, C. 2000. Decomposing Inequality in Greece: Results and Policy Implications. Discussion Paper DARP 49. London: Suntory and Toyota International Centres for Economics and Related Disciplines (STICERD), London School of Economics.

Postmes, T., and Branscombe, N. 2002. Influence of long-term racial environmental composition on subjective well-being in African Americans. Journal of Personality and Social Psychology 83 (3): 735-751.

Pradhan, M., Sahn, D., and Younger, S. 2001. Decomposing World Health Inequality Tinbergen Institute Discussion Papers 01-091/2. Amsterdam: Tinbergen Institute.

Pyong, G. M. 2006. Asian Immigration. In Pyong, G. M., ed., Asian Americans Contemporary Trends and Issues. London: Sage Publications.

Ranis, G., Stewart, F., and Ramirez, A. 2000. Economic Growth and Human Development. World Development 28 (2): 197-220.

Ruane, J. and Todd, J. 1996. The Dynamics of Conflict in Northern Ireland. Cambridge: Cambridge University Press.

Sakamoto, A., and Xie, Y. 2006. The Socioeconomic attainments of Asian Americans. In Pyong, G. M., ed., Asian Americans - Contemporary Trends and Issues. London: Sage Publications.

Shapiro, T. M., and Kenty-Drane, J. L. 2005. The Racial Wealth Gap. In Conrad, C. A., Whitehead, J., Mason, P., and Stewart, J. African Americans in the U.S. Economy. Lanham, MD: Rowman \& Littlefield.

Smith, R. C., and Seltzer, R. 2000. Contemporary controversies and the American racial divide. Lanham, MD: Rowman \& Littlefield.

Songsore, J. 2003. Regional Development in Ghana - The Theory and the Reality. Accra: Woeli Publishing Services. 
Stewart, F. 2001. Horizontal inequalities as a source of conflict. In Hampson, F., and Malone, D., eds, From Reaction to Prevention. London: Lynne Rienner.

Stewart, F. 2002. Horizontal inequalities: A neglected dimension of development. QEH Working Paper No. 81. Oxford: Queen Elizabeth House, University of Oxford.

Thernstrom, S., and Thernstrom, A. 1997. America in Black and White: One Nation, Indivisible. New York: Simon Schuster.

Tilly, C. 1998. Durable Inequality. Berkeley, CA: University of California Press.

Turton, D. 1997. War and ethnicity: global connections and local violence in North East Africa and Former Yugoslavia. Oxford Development Studies 25 (1): 77-94.

Ukiwo, U. 2005. The study of ethnicity in Nigeria. Oxford Development Studies 33 (1): 7-23.

van der Walle, D., and Gunewardena, D. 2001. Sources of ethnic inequality in Viet Nam. Journal of Development Economics 65 (1): 177-207.

Varshney, A. 2002. Ethnic Conflict and Civic Life: Hindus and Muslims in India. New Delhi; Oxford: Oxford University Press.

Whyte, 1983. How much discrimination was there under the unionist regime, 192168? In Gallagher, T., and O'Connell, J., eds, Contemporary Irish Studies. Manchester: Manchester University Press.

Xie, Y., and Goyette, K. 2004. A Demographic Portrait of Asian Americans. New York: Russell Sage Foundation. 